\title{
Time domains of the hypoxic ventilatory response in ectothermic vertebrates
}

\author{
Cosima Porteus • Michael S. Hedrick • \\ James W. Hicks · Tobias Wang $\cdot$ William K. Milsom
}

Received: 28 May 2010/Revised: 11 January 2011/Accepted: 19 January 2011/Published online: 11 February 2011

(C) The Author(s) 2011. This article is published with open access at Springerlink.com

\begin{abstract}
Over a decade has passed since Powell et al. (Respir Physiol 112:123-134, 1998) described and defined the time domains of the hypoxic ventilatory response (HVR) in adult mammals. These time domains, however, have yet to receive much attention in other vertebrate groups. The initial, acute HVR of fish, amphibians and reptiles serves to minimize the imbalance between oxygen supply and demand. If the hypoxia is sustained, a suite of secondary adjustments occur giving rise to a more longterm balance (acclimatization) that allows the behaviors of normal life. These secondary responses can change over time as a function of the nature of the stimulus (the pattern and intensity of the hypoxic exposure). To add to the complexity of this process, hypoxia can also lead to
\end{abstract}

Communicated by H. V. Carey.

C. Porteus $(\bowtie) \cdot$ W. K. Milsom

Department of Zoology, University of British Columbia,

Vancouver, BC V6T 1Z4, Canada

e-mail: ciuhandu@zoology.ubc.ca

W. K. Milsom

e-mail: milsom@zoology.ubc.ca

\section{S. Hedrick}

Department of Biological Sciences, California State University, East Bay, 25800 Carlos Bee Blvd., Hayward, CA 94542, USA

e-mail: michael.hedrick@csueastbay.edu

J. W. Hicks

Ecology and Evolutionary Biology, School of Biological

Sciences, University of California, Irvine, CA 92697, USA

e-mail: jhicks@uci.edu

T. Wang

Department of Zoophysiology, Aarhus University, 8000, Aarhus

C, Denmark

e-mail: tobias.wang@biology.au.dk metabolic suppression (the hypoxic metabolic response) and the magnitude of this is also time dependent. Unlike the original review of Powell et al. (Respir Physiol 112:123-134, 1998) that only considered the HVR in adult animals, we also consider relevant developmental time points where information is available. Finally, in amphibians and reptiles with incompletely divided hearts the magnitude of the ventilatory response will be modulated by hypoxia-induced changes in intra-cardiac shunting that also improve the match between $\mathrm{O}_{2}$ supply and demand, and these too change in a time-dependent fashion. While the current literature on this topic is reviewed here, it is noted that this area has received little attention. We attempt to redefine time domains in a more 'holistic' fashion that better accommodates research on ectotherms. If we are to distinguish between the genetic, developmental and environmental influences underlying the various ventilatory responses to hypoxia, however, we must design future experiments with time domains in mind.

Keywords Time domains - Acclimation/acclimatization . Hypoxic ventilatory response

\section{Introduction}

What are time domains and why consider them?

For most animals, the first response to environmental hypoxia is avoidance, followed quickly by an acute physiological response that minimizes the imbalance between oxygen supply and demand. If the hypoxia is sustained a suite of secondary adjustments occur giving rise to a more long-term balance (acclimatization) that allows the behaviors of normal life. These adjustments are, presumably, the 
raw material on which natural selection acts to produce physiological adaptations.

The extent to which ectothermic vertebrates respond to hypoxia and the manner in which they respond vary tremendously among species. What underlies these responses is the need to match oxygen delivery to the oxygen requirements of the mitochondria. Ventilation is the first step in the cascade that underlies this process. A wide spectrum of hypoxic ventilatory responses (HVR) have been reported for hypoxia-tolerant and intolerant species living in different habitats using different gas exchange organs to support different levels of metabolic demand.

As noted previously (Powell et al. 1998; Perry et al. 2009), the HVR arises from a complex interplay of many distinct processes. As a consequence, the HVR is dynamic and the nature of the response varies over time in a manner that, at least in part, depends on the nature of the stimulus (pattern and intensity of the hypoxic exposure) and the components of the HVR (e.g. respiratory volume or breathing frequency). In mammals, where emphasis has been placed on careful examination of these time-dependent changes, it has become clear that the responses are manifestations of distinct adjustments at multiple sites in the ventilatory control circuit ranging from the sensory inputs to the final motor output. Because some responses are sufficiently long-lasting after a hypoxic exposure to affect future responses to recurring bouts of hypoxia, reflecting a degree of memory or functional plasticity in the system, subtle differences in experimental protocols can elicit different combinations of time-dependent processes (Powell et al. 1998; Perry et al. 2009). If we are to distinguish between the genetic, developmental and environmental influences underlying physiological diversity, then it is critical that we carefully note which HVRs are being compared.

The ventilatory time domains defined from studies on adult mammals

In their 1998 review, Powell et al. (1998) proposed a common terminology for different components of the isocapnic HVR in adult mammals. Factors that decrease arterial $\mathrm{O}_{2}$ content independent of $\mathrm{O}_{2}$ partial pressure (e.g. anemia, carbon monoxide) were not considered, nor were other factors that alter ventilatory drive, such as the decrease in $\mathrm{CO}_{2}$ with hyperventilation from hypoxia. At that time, the list included mechanisms arising during or following brief hypoxic exposures (the acute response, short-term depression, short-term potentiation), mechanisms identifiable during or following episodic hypoxic exposures (progressive augmentation, long-term facilitation), and mechanisms identifiable during or following prolonged hypoxic exposures (hypoxic ventilatory decline, ventilatory acclimatization to hypoxia, ventilatory deacclimatization from hypoxia and hypoxic desensitization) (Fig. 1).

Note that the acute response was the response occurring in the first few breaths following changes in $\mathrm{O}_{2}$ levels at the peripheral chemoreceptors. The other short-term responses, occurring in seconds to minutes, involved mechanisms not dependent on changes in levels of gene expression or protein synthesis. Longer term responses to intermittent or chronic hypoxic exposure may involve mechanisms ranging from neurophysiological or neurochemical changes in the ventilatory control pathways, to subsequent changes in other aspects of respiratory drive, as well as changes occurring at other levels of the $\mathrm{O}_{2}$ transport cascade [e.g. the oxygen carrying capacity of red blood cells, modulation of cardiac function (particularly cardiac shunt) and vascular tone].

\section{A acute exposure}

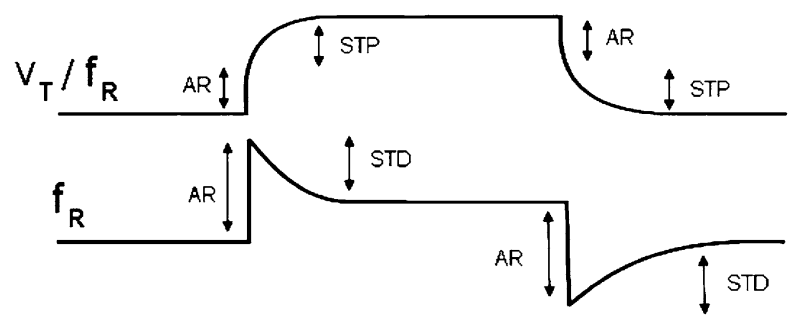

\section{B prolonged exposure}

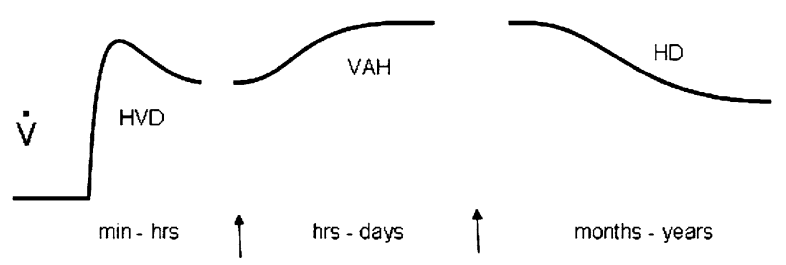

\section{C intermittent exposure}

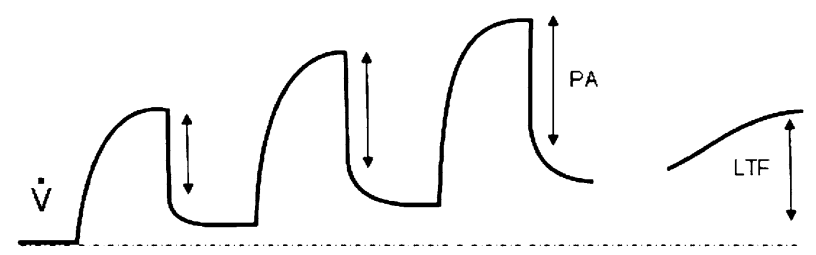

Fig. 1 Schematic diagram of ventilatory responses after a brief (seceonds to minutes) hypoxic exposure (AR acute response, STP short-term potentiation, STD short-term depression); b prolonged (minutes to years) hypoxic exposure ( $H V D$ hypoxic ventilatory decline, $V A H$ ventilatory acclimatization to hypoxia, $H D$ hypoxic desnsitization) and $\mathbf{c}$ intermittent hypoxic exposure ( $P A$ progressive augmentation, $L T F$ long-term facilitation) (modified after Powell et al. 1998) ( $V_{\mathrm{T}}$ tidal volume, $f_{\mathrm{R}}$ breathing frequency, $V$ total ventilation) 
Of particular note, many of these terms are difficult to apply to ectothermic vertebrates as the precise conditions under which these terms were defined are violated in studies of animals under more natural conditions. These terms all refer to changes in the HVR due to hypoxia per se (i.e. not to concomitant changes in drive from other sources) and each arose from a distinct and identifiably different mechanism. These are discussed in detail elsewhere (Powell et al. 1998). In virtually all studies of ectothermic vertebrates subsequent changes in respiratory drive accompany the HVR and these include not only the decreases in $\mathrm{CO}_{2}$ occurring as a result of the hypoxia induced increases in ventilation (the more natural condition), but also the decreases in metabolic rate that occur with hypoxia in many species. The latter has been termed the hypoxic metabolic response (HMR) (Barros et al. 2001; Powell and $\mathrm{Fu} 2008$ ) and to add to the complexity of the situation: the HMR has now also been shown to include time-dependent processes (Bishop et al. 2000; Seifert and Mortola 2002).

Temperature must also be considered when describing the time domains of the HVR of ectothermic vertebrates. Taking $Q_{10}$ effects (fold increase/decrease in the rate of change of reactions with a $10^{\circ} \mathrm{C}$ increase/decrease in temperature) into account, the time courses of the components of the HVR would be expected to be slower in ectothermic vertebrates than in mammals. Therefore, it is the mechanisms behind the time-dependent changes in ventilation rather than the time courses per se in ectothermic vertebrates that must be carefully considered in order to draw parallels to the time domains observed in mammals and to reflect on evolutionary trend in the HVR.

The need to consider time-dependent changes

in the HVR of ectothermic vertebrates

Over the past decade comparative physiologists have accepted the need to consider phylogeny when making comparisons between species involving the longest of time domains associated with physiological responses, physiological adaptation (Garland and Carter 1994; Garland and Adolph 1994). Not as much attention, however, has been paid to changes occurring over the shorter time domains associated with acute responses, with acclimatization to chronic or intermittent hypoxia, or during development.

Ectothermic vertebrates differ enormously in their hypoxia tolerance from resistance to anoxia in Crucian carp (Cyprinus carpio) and western painted turtles (Chrysemys picta bellii) (Glass et al. 1990; Lomholt and Johansen 1979; Ultsch and Jackson 1982) to high sensitivity to hypoxia in tuna, trout and soft-shelled turtles (Bushnell and Brill 1992; Crocker et al. 1999; Hughes and Sunders 1970; Perry and Gilmour 1996). A rich literature describes many aspects of this physiological diversity (Shelton et al. 1986;
Wang et al. 1998; Gargaglioni and Milsom 2007; Perry et al. 2009). There is also extreme variation in the experimental protocols used to determine the physiological responses to hypoxia with differences in the rate of change in the inspired gas composition, duration and intensity of the hypoxic exposure, the components of the HVR being examined (e.g. respiratory volume or breathing frequency) and the methods by which they were measured. For ectothermic vertebrates, this is further compounded by effects of temperature, diet, digestive status and perceived predation risk (Perry et al. 2009). Given this, the purpose of this review is to provide an overview of these diverse patterns within the framework of the time domains of the HVR. Wherever possible, this review also provides information about the developmental aspects of the HVR, an important consideration in ectotherms. This review is also set within the framework of the hierarchical levels of the $\mathrm{O}_{2}$ transport cascade and takes into consideration the levels of the ventilatory control circuit at which these responses occur.

\section{Fish}

Environmental hypoxia is often encountered in aquatic environments (Diaz and Breitburg 2009) and the HVR is arguably the most important physiological response that maintains blood gas homeostasis in fish during oxygen lack (Perry et al. 2009; Gamperl and Driedzic 2009). As mentioned earlier, in analyzing the ventilatory responses of any animal to hypoxia per se one should ideally maintain arterial levels of $\mathrm{CO}_{2} / \mathrm{pH}$ constant to eliminate the confounding effects of reducing the ventilatory drive as the hyperventilation induces hypocapnia. As other authors have indicated (Gilmour 2001; Perry et al. 2009), there is a respiratory alkalosis produced by the hyperventilation in fish and some species have been shown to be very sensitive to such small changes in arterial acid-base status (Gilmour 2001). Furthermore, elevation of red blood cell $\mathrm{pH}$ resulting from even a modest respiratory alkalosis can increase the affinity of hemoglobin for oxygen via the Bohr effect and increase arterial $\mathrm{O}_{2}$ content (Jensen 1991; Jensen et al. 1998). In most fish, however, arterial $\mathrm{PCO}_{2}$ levels are usually only a few $\mathrm{mmHg}$ above those of their environment as $\mathrm{CO}_{2}$ is readily eliminated at the gills (see Perry and Gilmour 2006 for a review) thus effects of hypoxia alone on the ventilatory response (without the complicating factor of large changes in $\mathrm{CO}_{2}$ seen in other terrestrial vertebrates) can be more easily assessed.

Responses to acute hypoxia in fish

Fish can encounter brief exposures to hypoxia either spatially (in the middle of large schools of fish (McFarland and Moss 1967), or moving through a water column) or 
temporally (seasonal changes in eutrophication) ( $\mathrm{Val}$ and De Almeida-Val 1995). The initial response of fish to hypoxia has been reviewed recently (Perry et al. 2009) and while there is much interspecific and intra-specific variation in the response, in general most species increase total gill ventilation by increasing ventilation amplitude with no or small increases in ventilatory frequency (Perry et al. 2009). There is large inter- and intra-species variability in this regard, however, with species that normally breathe episodically increasing ventilation frequency as they switch to continuous ventilation (Glass and Soncini 1999; Leite et al. 2007; Lomholt and Johansen 1979; Reid et al. 2003; Vulesevic et al. 2006) and other species increasing ventilation frequency in moderate hypoxia but ventilation amplitude in more severe hypoxia (Kinkead et al. 1991). The magnitude of the response is generally a hyperbolic increase in ventilation with decreasing levels of $\mathrm{PO}_{2}$ (Fritsche and Nilsson 1993; Perry and Gilmour 2002; Perry and Wood 1989; Shelton et al. 1986). The shape of the response generally reflects the position of the hemoglobin$\mathrm{O}_{2}\left(\mathrm{HbO}_{2}\right)$ equilibrium curve as well as the discharge characteristics of the peripheral $\mathrm{O}_{2}$ chemoreceptors (Burleson and Milsom 1995).

In mammals the primary mechanism responsible for the acute response is the increase in afferent discharge due to neurotransmitter release from peripheral chemoreceptors (the glomus cells of the carotid body). In fish the peripheral chemoreceptors appear to be neuroepithelial cells within the gills and orobranchial cavity. A subset of these have been shown to depolarize in response to hypoxia and to contain serotonin (Burleson et al. 2006; Jonz et al. 2004) and have been found in all species of fish studied to date (Coolidge et al. 2008; Saltys et al. 2006; for a more detailed review see Table 5.7 in Perry et al. 2009). In mammals the synaptic input from the chemoreceptors is "gated" in the nucleus of the solitary tract (NTS) in the medulla such that the immediate response differs depending on the phase of the ongoing respiratory cycle during which the afferent input arrives (Eldridge and Milhorn 1986). Whether this also occurs in fish is unknown although afferent nerve discharge from the peripheral chemoreceptors projects to a central sensory area homologous to the mammalian NTS (Sundin et al. 2003; Turesson and Sundin 2003).

While the ventilatory responses to hypoxia may be initiated very rapidly (within a breath or two) (Bamford 1974; Kinkead et al. 1991), typically in most studies, the time course over which environmental hypoxia was produced was sufficiently slow that it is hard to distinguish whether all of the short-term time domains (seconds to minutes) that have been described in mammals (the acute response, short-term potentiation and short-term depression) also occur in fish. Although scarce, data for fish do suggest that

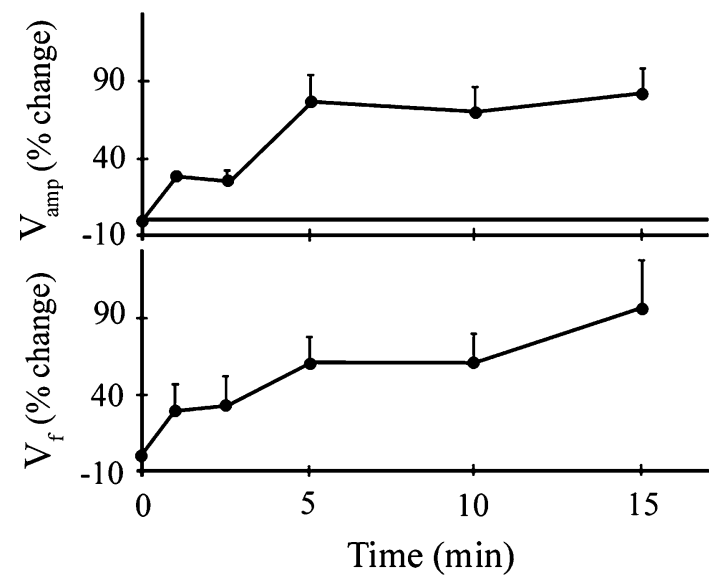

Fig. 2 Ventilation amplitude and frequency of the bowfin, Amia calva, during a $15 \mathrm{~min}$ exposure to moderate hypoxia $(47 \mathrm{mmHg})$ at $20^{\circ} \mathrm{C}$. The gradual increases in ventilation amplitude $\left(V_{\text {amp }}, t o p\right)$ and frequency $\left(V_{\mathrm{f}}\right.$, bottom $)$ indicates that short-term potentiation might be taking place. Values are mean + SEM (McKenzie et al. 1991)

the acute response and short-term potentiation take place. For instance, in Amia calva rapidly exposed to moderate hypoxia $(47 \mathrm{mmHg})$ at $20^{\circ} \mathrm{C}$ (McKenzie et al. 1991) there was an immediate (within $1 \mathrm{~min}$ ) increase in both respiration amplitude and frequency, followed by a plateau in the response (1-2 $\mathrm{min})$, followed by a progressive increase in ventilation amplitude and frequency that developed (2-15 min) (Fig. 2). Taking into account a $Q_{10}$ of $2-3$, the time course of this increase in ventilation in Amia likely reflects the short-term potentiation in mammals that develops within $1 \mathrm{~min}$. Until the mechanisms underlying these changes in fish are examined, however, this must remain speculative. Short-term potentiation is also manifest as a slow return of ventilation to original levels following return to normoxia but no studies yet have investigated the off response of fish exposed to hypoxia in any detail.

\section{Responses to intermittent hypoxia in fish}

Intermittent hypoxia is common in many aquatic environments. Fluctuations in water $\mathrm{PO}_{2}$ occur in small, shallow bodies of water due to the depletion of oxygen from animals respiring at night when photosynthesis stops. For example, intermittent hypoxia occurs in tidal pools where $\mathrm{PO}_{2}$ drops (sometime to almost anoxic levels) over a few hours and remains low until the next tide (Truchot and Duhamel-Jouve 1980). Similar fluctuations in $\mathrm{PO}_{2}$ have been reported in temporary lakes within the flood plains of the Amazon (Val and De Almeida-Val 1995). In the marine environment some deep sea fishes undergo daily migrations to the photic zone to feed, often traversing the oxygen minimum layer twice daily (Gordon 1969).

In mammals, short episodic hypoxic exposures (1-5 min) can produce progressive augmentation (increasingly greater 
responses to the same stimulus) and long-term facilitation (a slowly developing post-stimulus increase in breathing). Surprisingly, only a small number of studies have looked at HVRs of fish under fluctuating oxygen conditions. The length of the hypoxic exposures during each bout was generally much greater in these studies than in those in mammals (in order to more accurately reflect situations in the wild). None of the studies measured the changes in all components of the breathing pattern or of respiratory drive (including the HMR), however, precluding any detailed assessment of time domains (Taylor and Miller 2001). Thus, no conclusions can be drawn at this time.

\section{Responses to prolonged hypoxia in fish}

Seasonal variations in oxygen availability are seen in shallow temperate lakes (Val and De Almeida-Val 1995) or

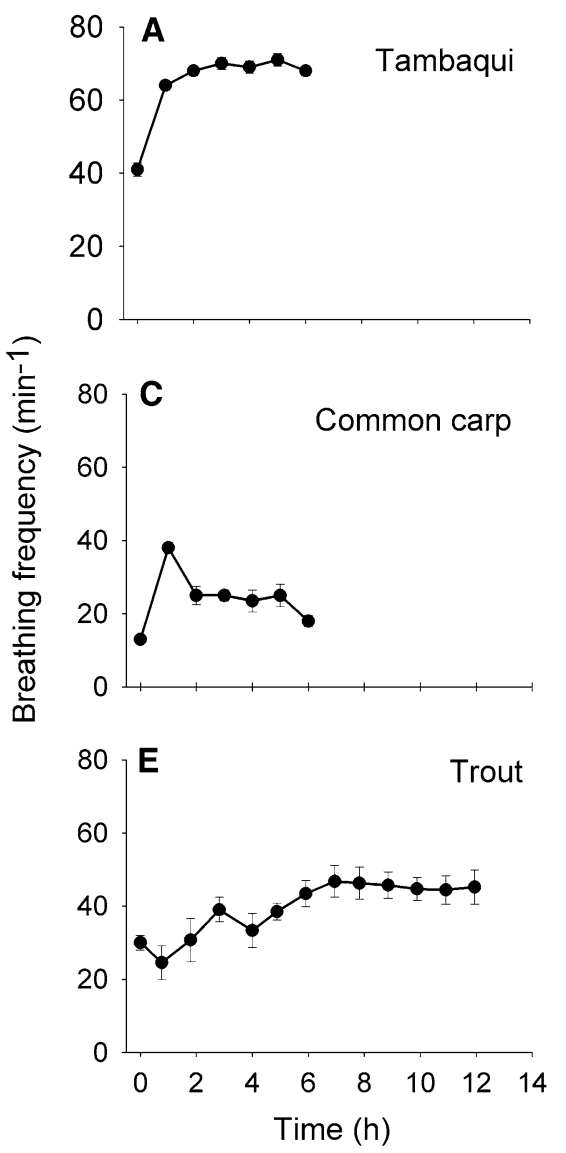

Fig. 3 Time domains of the HVR during prolonged exposure to hypoxia are evident in some species but not in others. Breathing a frequency and b) amplitude of tambaqui, Colossoma macropomum, during a $6 \mathrm{~h}$ exposure of severe hypoxia $(10 \mathrm{mmHg})$ at $25^{\circ} \mathrm{C}$ (modified from Florindo et al. 2006); c breathing frequency of common carp, Cyprinus carpio, during a $6 \mathrm{~h}$ exposure to near anoxia at $10^{\circ} \mathrm{C}$ (modified from Stecyk and Farrell 2002); d total ventilation of common carp (C. carpio) during a $4 \mathrm{~h}$ exposure to mild hypoxia $(75 \mathrm{mmHg}$ ) (modified from Glass et al. 1990); e Breathing frequency in hypoxic upwelling events in coastal marine systems where hypoxia can persist for months (Chan et al. 2008). Studies that look at changes in breathing frequency and amplitude over periods of time longer than a couple of hours in fish, however, are few, and for those that have, often the data are not presented at a fine enough scale to determine the presence of time domains. In most studies, the acute response appears to be sustained for hours to days and suggests that the hyperventilatory response to hypoxia is independent of the length of exposure (Borch et al. 1993; Florindo et al. 2006; Forgue et al. 1989; Glass et al. 1990; Thomas and Hughes 1982a, b) (Fig. 3a, d, e). Interestingly, this is despite accompanying a maintenance or increase in $\mathrm{Hb}-\mathrm{O}_{2}$-binding affinity and blood $\mathrm{O}_{2}$ carrying capacity during prolonged exposure to hypoxia (Nikinmaa 2001; Perry and Wood 1989; Wood and Johansen 1972) (Fig. 4). That said, there is some indication that time domains exist
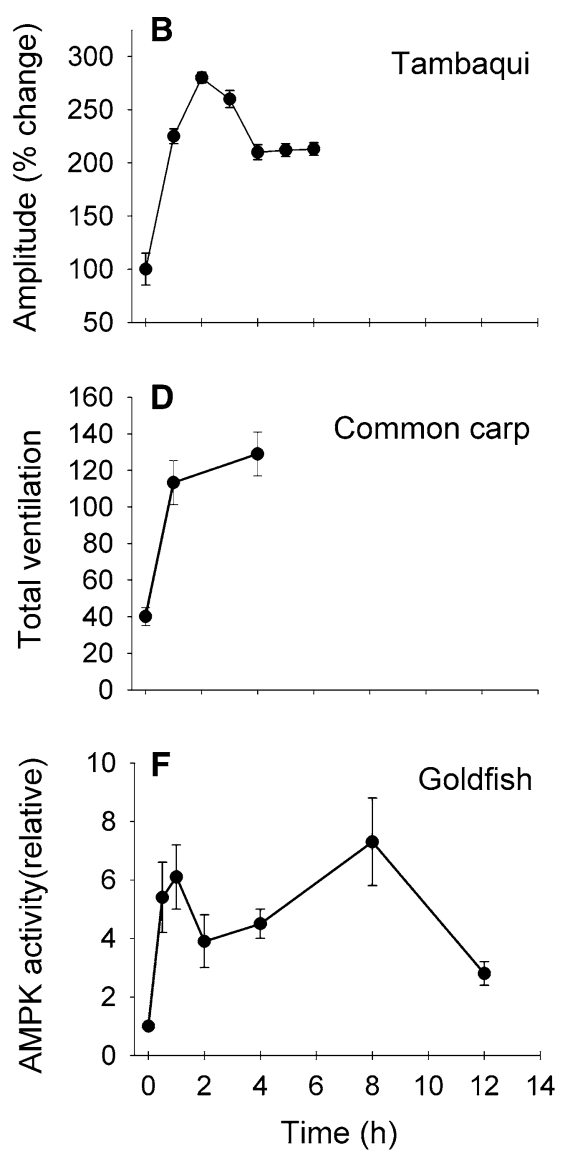

of trout (Oncorhynchus mykiss) exposed to $60 \mathrm{mmHg}$ for $12 \mathrm{~h}$ (modified from Borch et al. 1993); f AMP-activated protein kinase (AMPK) activity of goldfish, Carassius auratus, during a $0-12 \mathrm{~h}$ exposure of near anoxia at $10^{\circ} \mathrm{C}$ (modified from Jibb and Richards 2008). An increase in AMPK activity could be regulating a reduction in energy requirements of the cells, which could translate into a reduced ventilatory convection requirement, such as the changes seen in common carp breathing frequency or tambaqui breathing amplitude. Values are mean \pm SEM 


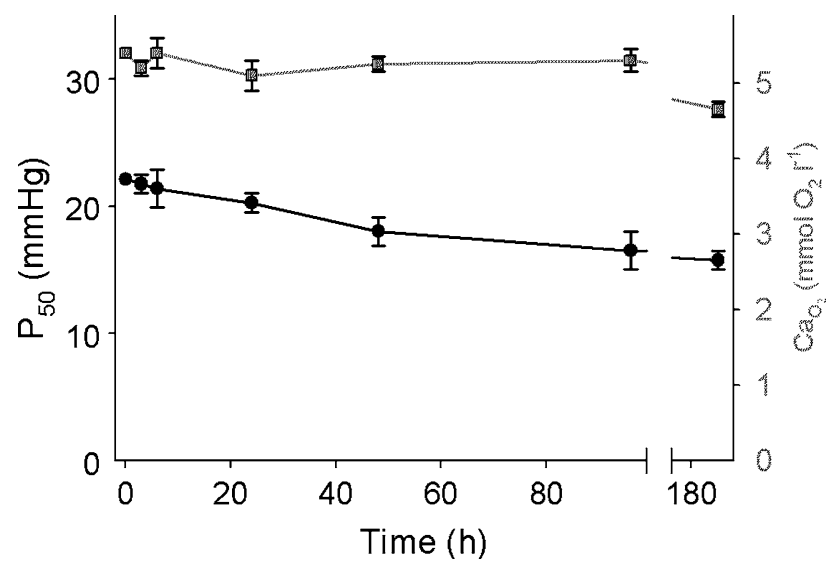

Fig. 4 Time-dependent changes are present in Hb-oxygen-binding affinity $\left(\mathrm{P}_{50}\right.$ black circles) but not in oxygen content $\left(\mathrm{Ca}_{\mathrm{O}_{2}}\right.$ dark gray squares) of trout (O. mykiss). This increase in oxygen-binding affinity (decrease in $\mathrm{P}_{50}$ ) takes place due to reduction of erythrocyte NTP concentration, without an overall increase in oxygen content (modified from Soivio et al. 1980)

in adult fish and their apparent absence in many studies may reflect a lack of resolution (see next section).

\section{Hypoxic ventilatory decline in fish}

It has been proposed that the hypoxic ventilatory decline that occurs in mammals with sustained hypoxia serves to conserve energy as breathing is energetically costly (Neubauer et al. 1990) and this strategy might also be beneficial for fish. The proposed mechanisms behind this decline in total ventilation in mammals are thought to be changes in ventilatory sensitivity and/or in central ventilatory drive. Most studies show a lack of response (Fig. 3a, d, e), however, a few studies have documented decreases in ventilation over periods of a few hours during sustained hypoxia. For example, tambaqui (Colossoma macropomum) exposed to severe hypoxia (10-20 $\mathrm{mmHg}$ ) initially exhibit the typical hyperventilation response, but ventilation amplitude then started to decrease slowly over the next $6 \mathrm{~h}$ of the exposure (Florindo et al. 2006; Rantin and Kalinin 1996) (Fig. 3b). Carp exposed to anoxia for $24 \mathrm{~h}$ at $6^{\circ} \mathrm{C}$ exhibited an initial fivefold rise in ventilation frequency over the first $2 \mathrm{~h}$ and then a ventilatory "roll-off" to initial levels over the next $14 \mathrm{~h}$ (Stecyk and Farrell 2002) (Fig. 3c). A similar response occurred at higher temperatures, however, over a shorter time course (see "The effects of temperature in ectotherms"). As in the studies on tambaqui, the level of hypoxia was severe and the decrease in ventilation frequency was probably at least in part due to a metabolic depression as well as to timedependent changes in the ventilatory response. These studies are the best evidence for the presence of hypoxic ventilatory decline in fish but if this is the hypoxic ventilatory decline, then this phenomenon that occurs within
5-30 min of hypoxic exposure in mammals takes several hours to develop in fish, a time course that could be explained by temperature differences alone.

Changes with similar time domains have been seen at the cellular level providing a possible explanation for the mechanisms behind these time-dependent changes in ventilation. AMP-activated protein kinase (AMPK) serves as a cellular regulator in order to match ATP supply and demand within the cell. During low oxygen availability, AMP activates AMPK which in turn inhibits anabolic processes and activates catabolic processes in the cell maintaining [ATP] stable. In goldfish, AMPK in the liver is activated after $30 \mathrm{~min}$ of exposure to hypoxia, decreased partially after about $3 \mathrm{~h}$ and increased again after $8 \mathrm{~h}$ of hypoxic exposure (Jibb and Richards 2008) (Fig. 3f). AMPK activity returned to pre-exposure levels after $12 \mathrm{~h}$ of exposure. Therefore, it is possible that the partial decrease in total ventilation of fish exposed to hypoxia for several hours represents a reduction in energy requirement at the cellular level regulated by AMPK and this in turn translates into a constant ventilatory convection requirement.

\section{Ventilatory acclimatization to hypoxia in fish}

The impact of chronic hypoxia on hypoxic sensitivity $\left(\Delta V_{\mathrm{w}} / \Delta \mathrm{PO}_{2}\right)$ is variable in fish. In flounder (Platichthys flesus) gill ventilation increased twofold after a 3-week acclimatization to hypoxia $(30 \mathrm{mmHg}$ ) compared to fish acutely exposed to the same level of hypoxia (Kerstens et al. 1979) (Fig. 5). Similarly, channel catfish (Ictalurus punctatus) exposed to moderate hypoxia for 7 days increased resting breathing frequency and ventilatory sensitivity to hypoxia (Burleson et al. 2002) (Fig. 5). In other species, however, no changes or reduced ventilation/sensitivity have also been reported (C. carpio, Lomholt and Johansen 1979; Lampetra fluviatilis, Nikinmaa and Weber 1984; Danio rerio, Vulesevic et al. 2006). These differences might reflect differences in coping strategies between species or simply could be due to differences in the time and severity of the hypoxic acclimation. No studies to date have looked at the off response (the change in ventilation on return to normoxia) of fish exposed to chronic hypoxia.

To the extent that changes occur in sensitivity, these may reflect plasticity at the chemoreceptor level. Thus, zebrafish (D. rerio) exposed to chronic hypoxia (35 mmHg, 60 days) exhibited hypertrophy and changes in morphology (Jonz et al. 2004), but not proliferation of serotonin containing neuroepithelial cells (Jonz et al. 2004; Vulesevic et al. 2006).

The mechanisms behind VAH in mammals involve changes in plasticity at both the chemoreceptor level and the level of the central nervous system. The latter include 


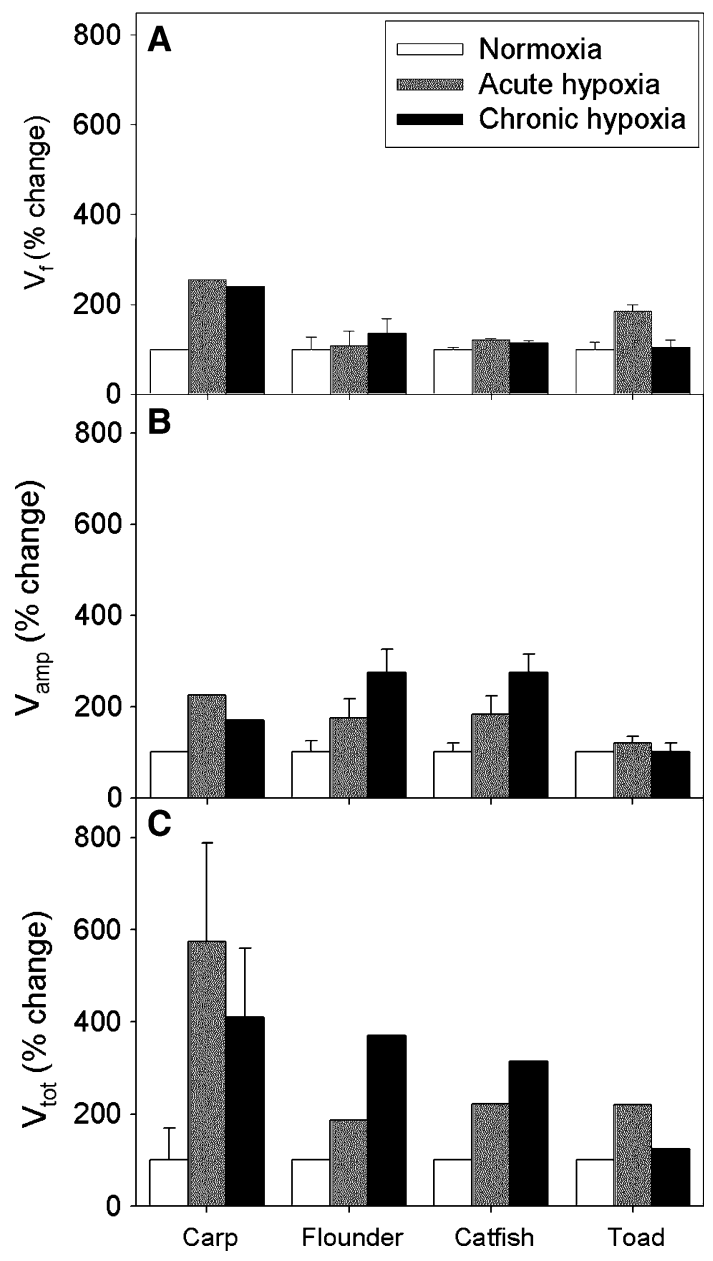

Fig. 5 Effect of chronic hypoxic exposure $(30-70 \mathrm{mmHg}$ for 1-4 weeks) on the a ventilation rate, $\mathbf{b}$ ventilation amplitude and c total ventilation of three different species of fish (carp Cyprinus carpio, flounder Platichthys flesus, and catfish Ictalurus punctatus) and the Cane toad, Rhinella marina. Ventilatory acclimatization to hypoxia is evident in some fish species (flounder and catfish) but not in others (carp). Toads do not exhibit a mammalian-like ventilatory acclimatization to hypoxia. In contrast, non-acclimated toads exhibit a robust ventilatory response to the same level of acute hypoxia. Values are mean \pm SD/SEM (modified from Lomholt and Johansen 1979; Kerstens et al. 1979; Burleson et al. 2002; McAneney et al. 2006)

changes in gene expression mediated by hypoxia inducible factor $1 \alpha$ (HIF-1 $\alpha$ ) (Powell and Fu 2008). Similar changes in gene expression have also been shown in fish exposed to $10 \%$ oxygen saturation for up to 6 days and they likely involve regulation by HIF- $1 \alpha$ (Gracey et al. 2001). This suggests that changes in gene expression and their mechanisms are conserved between vertebrate classes and are critical for acclimatization to chronic hypoxia. In fish these changes reflect tissue specific and time-dependent decreases in the expression of genes involved in protein synthesis, cell growth, proliferation and muscle contractility and increases in expression of genes involved in ATP metabolism and glycolysis (Gracey et al. 2001).
Developmental changes in the HVR in fish

The developmental strategies of fishes vary greatly but generally the embryos are small and covered in an egg capsule called a chorion. Fish embryos encounter hypoxia often as they are normally buried under gravel where dissolved oxygen levels are low (Youngson et al. 2004) and their large yolk sacks hinder them from escaping this environment. During early development the surrounding chorion is thought to limit oxygen diffusion to the embryo (Rombough 1998; Ciuhandu et al. 2007). Fish embryos obtain their oxygen by diffusion across the skin. When embryos are small diffusion is sufficient to meet oxygen requirements because the skin surface is large and diffusion distances are small. As the embryos grow the ratio of surface area to volume decreases and at $\sim 100 \mathrm{mg}$ the surface area of the skin becomes limiting for gas exchange and gills take over as the major organ for respiratory gas exchange (Rombough and Moroz 1997).

All fish studied to date (Arctic char, trout and zebrafish) develop irregular breathing movements soon after hatching and the breathing movements become regular later in development (Holeton 1971; McDonald and McMahon 1977; Jonz and Nurse 2005; Turesson et al. 2006). Fish larvae display an acute HVR soon after hatching and this response becomes more robust later in development (Holeton 1971; McDonald and McMahon 1977). Furthermore, fish larvae reared in hypoxia develop a regular breathing pattern earlier than fish reared in normoxia (McDonald and McMahon 1977).

At hatch, gill filaments are present, but they are small and tightly packed and, as development continues, the filaments become more spread out on the gill arch and lamellae develop (McDonald and McMahon 1977; Jonz and Nurse 2005). Interestingly, although neuroepithelial cells are present at the time of hatch in zebrafish, they become innervated only just before the time of complete yolk reabsorption (after a hypoxic hyperventilatory response develops), indicating that this oxygen-sensing pathway becomes functional only closer to emergence (Jonz and Nurse 2005). It has also been shown that there is a central switch in receptor-mediated ventilatory control with the late onset of dependence on glutamatergic transmission (NMDA receptor-mediated) just before branchial respiration begins (Turesson et al. 2006). It is not at all clear what receptors are active early in development before the neuroepithelial cells are innervated and what non-NMDA receptor mechanisms are responsible for the central integration of the hypoxic response at this time.

Thus it would appear that time-dependent changes in the HVR arise during development in fish. It will be interesting to examine when this occurs in different species, and how 
this compares to the changes seen in amphibian tadpoles (see "Developmental changes in the HVR of larval amphibians"). It must be kept in mind, however, that determining the onset of time-dependent changes in the HVR (acclimation) during development, are confounded by developmental changes in oxygen requirements.

The HVR in fish exhibiting aquatic surface respiration or air breathing

Some fish have evolved ways to increase their oxygen supply when faced with aquatic hypoxia by exhibiting aquatic surface respiration or air breathing. Fish employing aquatic surface respiration can use the oxygen enriched layer at the surface of the water-air interface to obtain more oxygen during gill breathing. Facultative air breathing fish normally use their gills to supply their oxygen needs, however, when water becomes hypoxic, they have the ability to come to the surface and supplement their oxygen needs by gulping air. They employ a variety of air breathing organs, including modified gas bladders, suprabrachial chambers, or modifications of the digestive system (Graham 1997). The typical response to hypoxia of both fish employing aquatic surface respiration and facultative air breathing is an initial increase in gill ventilation. However, if the increase in gill ventilation is not sufficient to meet oxygen needs then aquatic surface respiration or air breathing increases (Hedrick et al. 1994; Rantin and Kalinin 1996). In the latter case, gill breathing is also inhibited, which is thought to prevent loss of oxygen to the hypoxic aquatic environment (Johansen et al. 1970). In these instances, there may be timedependent changes in the threshold at which the ventilatory responses will alter arterial $\mathrm{PO}_{2}$ at any given level of aquatic $\mathrm{PO}_{2}$ making further interpretation of the mechanisms underlying time-dependent changes in breathing extremely difficult. It is unclear whether obligate air breathers respond to aquatic hypoxia; in some studies fish show an increase in air breathing (Babiker 1979; Glass et al. 1986; Jesse et al. 1967; Johansen and Lenfant 1967) while in other studies on the same species they show no response (Johansen and Lenfant 1968; Perry et al. 2005; Sanchez et al. 2001). In all genera of lungfish, aerial hypoxia stimulates air breathing (Jesse et al. 1967; Johansen and Lenfant 1968; Babiker 1979; Pack et al. 1990; Sanchez et al. 2001; Perry et al. 2005, 2008) and this was also the case in terrestrialized (cocooned) Protopterus dolloi (Perry et al. 2008). These results are in contrast to data obtained from aestivating toads (see "Consequences of circadian and circannual cycles in ectotherms"). There are, however, no studies of the time domains of the air breathing response to aerial hypoxia in aquatic or aestivating air breathing fish.

\section{Tetrapods}

As with fish, investigating the HVR in ectothermic tetrapods is complicated by the influence of variable body temperature and hypoxia-induced metabolic suppression (see below). An additional complication arises from the undivided hearts in amphibians and reptiles that give rise to cardiac shunts that are under autonomic control and change consistently with ventilation (Wang et al. 1997). In combination with the direct influence of changes in body temperature and hypoxia-induced metabolic suppression, cardiac shunts influence arterial blood oxygen levels.

\section{Consequences of cardiac shunts in tetrapods}

Because of the undivided ventricle, amphibians and reptiles are capable of producing both left-to-right (L-R or systemic to pulmonary) and right-to-left ( $\mathrm{R}-\mathrm{L}$ or pulmonary to systemic) shunts. An L-R shunt represents recirculation of pulmonary venous blood (oxygen rich) into the pulmonary circulation. This shunt does not directly affect arterial oxygen levels, but the rise in pulmonary blood flow can "steal" systemic output, and thus, lower oxygen delivery to the systemic tissues (Wang and Hicks 2002). In the presence of a R-L shunt, on the other hand, oxygen poor venous blood bypasses the lungs, and re-enters the systemic circulation without being oxygenated. The shunted systemic venous blood, therefore, decreases arterial oxygen saturation resulting in arterial hypoxemia and reductions in tissue oxygen delivery. Furthermore, in animals with $\mathrm{L}-\mathrm{R}$ cardiac shunts, the arterial blood gases do not directly reflect lung gas composition. This uncoupling of lung and blood gases, which normally does not occur in birds and mammals, implies that changes in the cardiac shunt pattern can contribute to the regulation of arterial blood gases. In the presence of shunts, the arterial $\mathrm{PO}_{2}$ and $\mathrm{PCO}_{2}$ are determined by the gas contents of arterial and venous blood, the magnitude of the shunt and the respective blood gas affinities and capacities (for reviews see Hicks and Wang 1996; Wood 1982, 1984; Wang and Hicks 1996). Because cardiac shunts affect arterial blood gas content, there exists the potential, not possible in birds and mammals, to alter the direction and magnitude of cardiac shunting as a means to regulate arterial blood gas composition independently of lung ventilation (e.g. Burggren et al. 1989; Wang et al. 1997). Furthermore, Wang and Hicks (1996) argued, theoretically, that changes in cardiac shunts may be a more powerful determinant of arterial $\mathrm{PO}_{2}$ than changes in lung ventilation (Fig. 6). By increasing arterial $\mathrm{PO}_{2}$ these shunts reduce the need for the HVR and any time-dependent changes in shunt fraction will contribute to the time-dependent changes in the HVR. Unfortunately, the sensory mechanisms that may regulate 


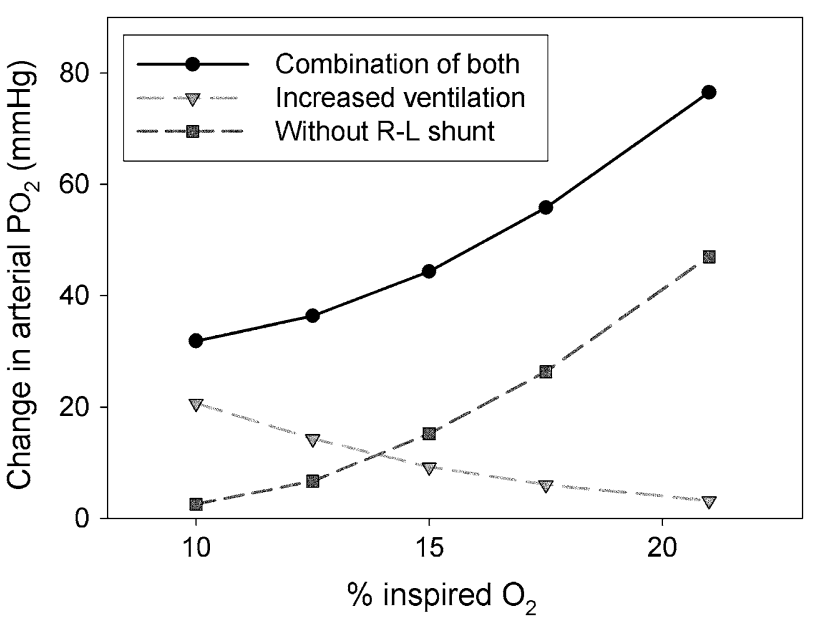

Fig. 6 Calculated change in arterial $\mathrm{PO}_{2}$ at various levels of hypoxia (percent of inspired oxygen) achieved by increasing ventilation (triangle), eliminating the $\mathrm{R}-\mathrm{L}$ shunt (squares), or by a combination of both increasing ventilation and eliminating the $\mathrm{R}-\mathrm{L}$ shunt (circles) (modified from Wang and Hicks 1996). Note that at higher levels of inspired oxygen, changes in ventilation have little effect while changes in shunt fraction produce large effects. The opposite is true at lower levels of inspired oxygen

cardiac shunts have not been studied in detail and it remains a major challenge to understand how cardiovascular and ventilatory control mechanisms are integrated in the control of arterial oxygen delivery in amphibians and reptiles (Wang et al. 1997).

\section{Amphibians}

Amphibians are the first vertebrates to successfully invade terrestrial habitats. Extant members of the three orders of Amphibia—Gymnophiona, Caudata and Anura-represent a monophyletic group comprising approximately 6,000 species (Hillman et al. 2009). Among the three groups, the respiratory physiology of the Anura (frogs) has received far more attention that either Caudata (salamanders) or Gymnophiona (caecilians). A confounding feature with examining HVRs of all three groups is the radical change that occurs with development in the majority of these animals. Most amphibians have larval forms that are entirely "aquatic" (see Burggren and Just 1992) whereas following metamorphosis, adult forms may range from entirely aquatic to completely terrestrial. Aquatic larval or adult amphibians are more likely than their terrestrial counterparts to experience bouts of hypoxia on a daily or seasonal basis. Terrestrial adult amphibians would not normally experience environmental hypoxia except in situations such as burrowing (estivation). Estivating/burrowing animals undergo reductions in metabolic rate (Glass et al. 1997; Guppy and Withers 1999) and ventilation (Boutilier et al. 1979), but compensatory adjustments in ventilation to hypoxia during estivation have not been examined. Nonetheless, amphibians regularly experience large fluctuations in arterial $\mathrm{PO}_{2}$, resulting from intermittent breathing patterns (brief ventilatory periods, intermixed with variable periods of apnea) exacerbated by a variable intra-cardiac shunt.

Responses to acute hypoxia in amphibians

\section{Caecilians}

Few studies have investigated the effects of hypoxia on ventilation in this group (see Jared et al. 1999 for review). With the exception of one lungless aquatic species (Atretochoana eiselti; Nussbaum and Wilkinson 1995), all caecilians use lung ventilation and cutaneous diffusion to exchange respiratory gases. Acute exposure to aquatic hypoxia as low as $40 \mathrm{mmHg}$ had no effect on lung ventilation in the aquatic caecilian $T$. natans although exposure to the same level of hypoxia in the aerial environment resulted in a significant increase in respiratory frequency, primarily due to a decrease in non-ventilatory periods (apneas), with no change in respiratory volume (Gardner et al. 2000). Because aquatic caecilians likely use their lungs for buoyancy as well as gas exchange, changes in respiratory volume may be used primarily for buoyancy control while respiratory frequency adjustments are used solely for regulating gas exchange. Nothing else is known about the HVR in this group. Because many caecilians are fossorial and/or aquatic (Jared et al. 1999), and possibly experience extended periods of hypoxia, it would be interesting to examine the HVR and its time domains in this understudied group of amphibians.

\section{Salamanders}

There have also been only a few studies of the HVR of salamanders. The aquatic, neotenous axolotl, Ambystoma mexicanum, exhibited a significant increase in gill ventilation and air breathing frequency in response to $1 \mathrm{~h}$ of hypoxia $(\sim 22 \mathrm{mmHg})$ indicating a robust acute HVR (McKenzie and Taylor 1996). External and internal bolus injections of sodium cyanide $(\mathrm{NaCN})$ also stimulated both gill ventilation and air breathing in this species, suggesting that oxygen-sensitive chemoreceptors contributing to the HVR monitor both the water and blood (McKenzie and Taylor 1996). In the plethodontid salamander, Desmognathus fuscus, graded hypoxia caused an increase in buccal activity, which is thought to provide additional gas exchange despite the absence of lungs (Sheafor et al. 2000). These studies indicate that the short-term HVR in salamanders is typical of amphibians and other vertebrates. 
To our knowledge, longer time domains of the HVR in salamanders have not been investigated. The time domains associated with gill versus air breathing responses have not been studied either.

\section{Anurans}

All anurans, with the exception of the recently discovered lungless frog, Barbourula kalimantanensis (Bickford et al. 2008), use lungs for gas exchange as adults. In anurans, four basic breath types have been identified: buccal oscillations, balanced breaths, inflation breaths and deflation breaths (Jones 1982; Wang 1994; de Jongh and Gans 1969; West and Jones 1975; MacIntyre and Toews 1976; Vitalis and Shelton 1990; Sanders and Milsom 2001). The pattern in which these breaths are combined varies tremendously amongst anuran species, in part due to differences in metabolic rate and respiratory drive, and any discussion of ventilation in anurans must necessarily address the variability in breathing patterns seen in this group (see reviews by Shelton et al. 1986; Boutilier 1988; Milsom et al. 1999; Jørgensen 2000; Gargaglioni and Milsom 2007). In normoxia, the typical breathing pattern consists of buccal oscillations interrupted by single breaths or bouts of episodic breathing consisting of two or more lung breaths in succession. When metabolic rate is low and animals are undisturbed, the periods of apnea between breaths or episodes may be extensive. Apneas of up to $8 \mathrm{~h}$ have been recorded in resting toads [Bufo marinus (=Rhinella marina)] resulting in arterial $\mathrm{PO}_{2}$ of $<20 \mathrm{mmHg}$ (Coelho and Smatresk 2003). This suggests that arterial hypoxemia does not necessarily provide a strong ventilatory stimulus under resting conditions and that blood gases are only loosely coupled to ventilation. It has been suggested that part of this loose coupling of ventilation to blood gases may be a consequence of the use of ventilation to drive lymph movement in anurans (Hedrick et al. 2007; Hillman et al. 2010).

Acute exposure (minutes) to moderate levels of hypoxia $\left(0.10-0.15 \mathrm{FI}_{\mathrm{O}_{2}}\right)$ in resting anurans causes an immediate increase in ventilation (Kruhøffer et al. 1987; Wang et al. 1994; Branco and Glass 1995; Withers and Hillman 1983). In some studies this was mediated primarily by increases in tidal volume (Gamperl et al. 1999; Gargaglioni and Branco 2000) or buccal amplitude (a proxy for tidal volume, see Wang 1994; Smatresk and Smits 1991). In other studies, it was due to an increase in breathing episodes and lung inflation cycles (Pinder and Burggren 1986; Rocha and Branco 1998; Hou and Huang 1999; Gargaglioni and Branco 2000). Typically, progressive hypoxia produces a decline in buccal oscillations and an overall increase in lung ventilation that returned to normal following the hypoxic exposure (Boutilier and Toews 1977). However,
Rana pipiens exposed to complete anoxia show an acute short-term depression leading to cessation of breathing within 30 min (Rose and Drotman 1967).

Lung ventilation is stimulated by hypoxic hypoxia rather than reductions in oxygen hemoglobin carrying capacity induced by anemia (Wang et al. 1994; Andersen et al. 2003) or exposure to carbon monoxide (Branco and Glass 1995 ) indicating that arterial $\mathrm{PO}_{2}$, and not oxygen content, is the primary stimulus for ventilation. The oxygen-sensitive chemoreceptors that stimulate breathing are located in the carotid labyrinth, the aortic arch and pulmocutaneous artery (West and Van Vliet 1992; Burggren and Pan 2009; Van Vliet and West 1992; Wang et al. 2004; Kusakabe 1991, 1992; Kusakabe et al. 1993). Denervation of the carotid labyrinth alone in Xenopus laevis failed to abolish the HVR (Jones and Chu 1988), suggesting that the other two sites are capable of producing a full response. Neuroepithelial bodies, containing putative oxygen-sensing cells, have also been found in the lungs of amphibians, suggesting that the oxygen composition of respiratory gas may also be monitored (Goniakowska-Witalinska et al. 2009). More recently, it has been suggested that central $\mathrm{O}_{2}$ sensitive chemoreceptors may also be involved in this response (see next section) (Reid 2006; McAneney and Reid 2007).

The nucleus isthmi (NI), a bilateral mesencephalic structure, has been shown to play a role in reducing the acute HVR in the toad Bufo paracnemis. Lesioning the NI in toads had no effect on resting ventilation, but when toads were exposed to hypoxia ( 5 or $7 \% \mathrm{O}_{2}$ ), both tidal volume and breathing frequency increased significantly more than in sham-operated animals (Gargaglioni and Branco 2000), suggesting that the NI has a descending inhibitory influence on the HVR. The inhibitory influence of the NI appears to involve nitric oxide (NO) as blocking NO synthesis in the NI mimicked the effects of NI lesions (Gargaglioni and Branco 2001).

Responses to prolonged hypoxia in anurans

The role of prolonged or chronic exposure to hypoxia on ventilatory responses has been given very little attention in anurans. Although the acute response to hypoxia in anurans is typically a ventilatory increase, hypoxic exposure of post-metamorphic or adult brainstems in vitro is characterized by a short-term respiratory depression (Winmill et al. 2005; Fournier and Kinkead 2006, 2008; Fournier et al. 2007). In isolated brainstems from post-metamorphic and adult bullfrogs, exposure to severe hypoxia $(98 \%$ $\mathrm{N}_{2} / 2 \% \mathrm{CO}_{2}$ ) caused a reduction in fictive ventilation that occurred within about $30 \mathrm{~min}$ (Winmill et al. 2005). This hypoxic ventilatory decline appears to be mediated, in part, by ATP and/or adenosine since blocking K(ATP) channels 
and adenosine receptors delayed the onset of hypoxic ventilatory decline by about $60 \mathrm{~min}$ (Hedrick and Chen 2009) (Fig. 7a). The hypoxic ventilatory decline of adult brainstems also contains a noradrenergic component that acts via GABA/glycine pathways (Fournier et al. 2007) (Fig. 7b) and may arise from the locus coeruleus (Fournier and Kinkead 2008) indicating that cells within the locus coeruleus may sense $\mathrm{O}_{2}$ as well as $\mathrm{CO}_{2}$, as previously demonstrated (Noronha-de-Souza et al. 2006). These data may indicate that there is an interactive balance between stimulation of ventilation mediated by peripheral chemoreceptors and central respiratory depression due to stimulation of central chemoreceptors (possibly at multiple sites) taking place during prolonged hypoxia (Reid 2006).
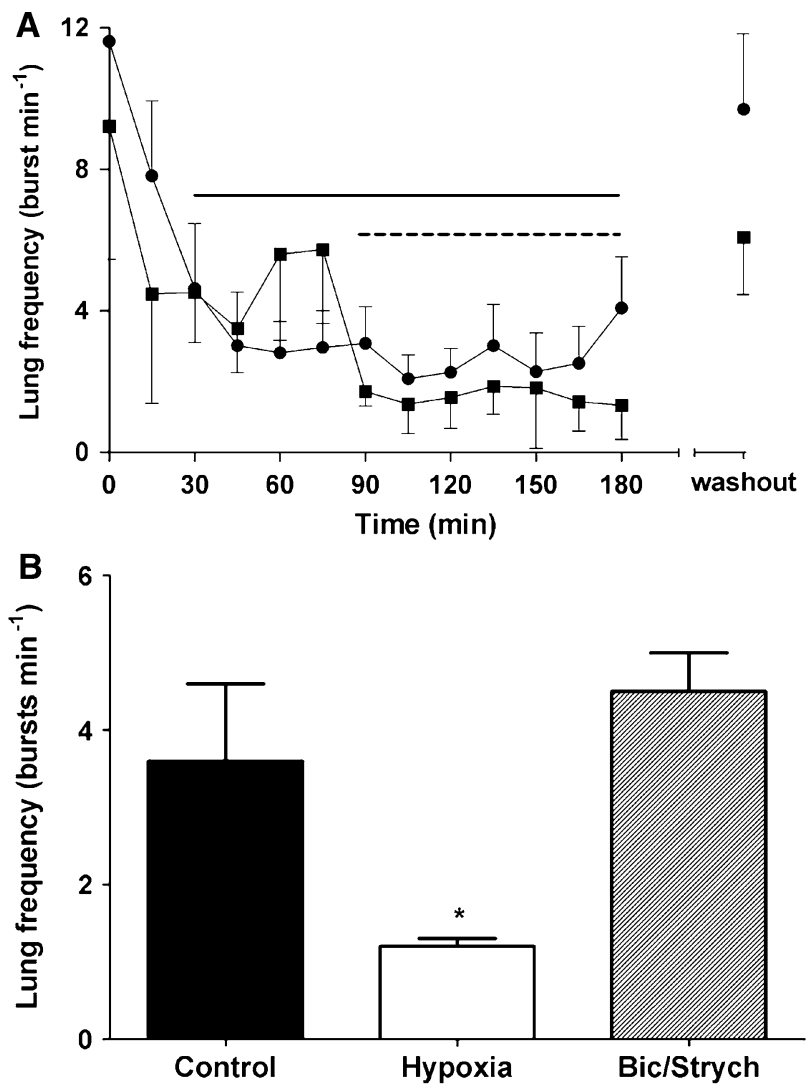

Fig. 7 Hypoxic ventilatory decline in the bullfrog brainstem. a Postmetamorphic brainstems exposed to $3 \mathrm{~h}$ of hypoxia (filled circles) exhibited HVD within $30 \mathrm{~min}$ and was sustained throughout the hypoxic exposure (solid line). Blocking K(ATP) channels with a mixture of 2,3-butanedione monoxime (BDM; $500 \mu \mathrm{M})$ and the adenosine receptor antagonist, theophylline $(100 \mu \mathrm{M})$ (filled squares) during hypoxia delayed the onset of respiratory depression by approximately $60 \mathrm{~min}$ (dashed line). In both experiments, reoxygenation of aCSF during washout restored lung burst frequency to control levels (modified from Hedrick and Chen 2009); b in adult bullfrogs, hypoxia causes a significant ventilatory depression within $10 \mathrm{~min}$ that is blocked by a mixture of bicuculline $(1.25 \mu \mathrm{M})$ and strychine $(1.5 \mu \mathrm{M})$ which block $\mathrm{GABA}_{\mathrm{A}}$ and glycine receptors, respectively (modified from Fournier et al. 2007)
In adult cane toads chronic (10 days) exposure to hypoxia $(\sim 70 \mathrm{mmHg})$ did not affect resting breathing frequency, but blunted the HVR, a result opposite of that found in mammals, suggesting that adult amphibians do not undergo ventilatory acclimatization to hypoxia (Gamperl et al. 1999; McAneney et al. 2006) (Fig. 5). Blood gases were not measured in this study, however, making it difficult to establish whether similar changes occurred in $\mathrm{Pa}_{\mathrm{O}_{2}}$ and $\mathrm{Pa}_{\mathrm{CO}_{2}}$ as in control animals. However, isolated brainstems from these animals also showed a blunted response to hypoxia as well as to changes in $\mathrm{pH} / \mathrm{CO}_{2}$ (McAneney and Reid 2007). The latter was abolished by midbrain transection, again illustrating a descending inhibitory role of higher brain structures on ventilatory activity produced by the medulla (McAneney and Reid 2007). Chronic exposure to hypoxic hypercapnia $(10 \%$ $\mathrm{O}_{2} / 3.5 \% \mathrm{CO}_{2}$ ), also blunted the ventilatory response to hypoxia in intact animals (Srivaratharajah et al. 2008). In isolated brainstems from these toads, respiratory frequency was augmented due to an increase in the number of breathing episodes/minute (Srivaratharajah et al. 2008). Overall these results indicate that anuran amphibians do not exhibit ventilatory acclimatization to hypoxia, as seen in some fish and mammals, although it is clear that prolonged hypoxic (and hypercapnic) exposure modifies the ventilatory responses to subsequent exposures to hypoxia, indicating that respiratory plasticity does occur in anurans.

Finally, toads (Bufo bankorensis) collected from populations at higher elevations (ca. 3,000 m) exhibit significantly more ventilatory periods and increased total inspired volume compared with lowland conspecifics when exposed to severe hypoxia $\left(\mathrm{PO}_{2}=40 \mathrm{mmHg}\right.$; Hou and Huang 1999) indicating a small degree of increased hypoxic sensitivity may occur over generations.

Developmental changes in the HVR of larval amphibians

Anuran tadpoles are capable of using skin, gills and lungs for gas exchange and previous work with bullfrog tadpoles [Rana catesbeiana (=Lithobates catesbeianus)] indicates that all three sites are utilized to acquire oxygen (Burggren and West 1982). Studies with bullfrog tadpoles have shown that hypoxia produces increases in both gill and lung ventilation (West and Burggren 1982) and the general view is that the relative importance of lung ventilation for oxygen acquisition in normoxia and hypoxia increases with development; however, there are some discrepancies between studies in terms of the acute HVR. For example, Burggren and Doyle (1986) reported that hypoxia increased gill ventilation in tadpoles up to stage XIV (Taylor and Kollros 1946 staging), but had no significant effect on lung ventilation frequency in tadpoles younger than stage XX. 
In a more recent study, however, animals of all stages increased 'surfacing events' in response to hypoxia (Crowder et al. 1998). The data from the latter study indicate that bullfrog tadpoles are facultative air breathers up to stage XXII when the gills regress. They subsequently become obligate air breathers (Crowder et al. 1998). The discrepancies between the two studies may be due to methodological differences: the study by Burggren and Doyle (1986) used animals that were instrumented to record buccal pressures while the animals in the Crowder et al. (1998) study were not instrumented and data were collected by direct observation.

Ventilatory responses to hypoxia by larval bullfrogs are mediated primarily by oxygen-sensitive chemoreceptors located on the first gill arch (Jia and Burggren 1997a, b) as the initial ventilatory response (i.e. $<20 \mathrm{~s}$ ) to hypoxia or central injection of $\mathrm{NaCN}$ in larval bullfrogs, is abolished by ablation of the first gill arch (Jia and Burggren 1997a, b) regardless of the age of the animals. The presence of oxygen-sensitive chemoreceptors on the first gill arch in the tadpoles has been confirmed by recording afferent neural activity from the first gill arch in response to hypoxia (Straus et al. 2001).

Exposure of tadpoles (L. catesbeianus) to chronic hypoxia $\left(\mathrm{PO}_{2}=70-80 \mathrm{mmHg}, 4\right.$ weeks $)$ produced profound changes in the morphology of the respiratory system including a reduction in the gill/water gas barrier and an increase in lung volume (Burggren and Mwalukoma 1983). Chronic hypoxia in adult bullfrogs did not elicit similar morphological changes in the respiratory system indicating either that significant morphological changes to the respiratory system occur with aquatic hypoxia (tadpoles) rather than aerial hypoxia (adults), or that such changes can only occur early in development. How these morphological changes in response to chronic hypoxia affect the HVR remains unknown.

More recent experiments have focused on the possible role of oxygen-sensitive chemoreceptors within the central nervous system in tadpoles. Hypoxic exposure of the pre-metamorphic bullfrog brainstem in vitro produces a brief stimulation of lung ventilation (Fournier and Kinkead 2008) followed by a hypoxic ventilatory decline that requires approximately $3 \mathrm{~h}$ to develop in the pre-metamorphic brainstem (Winmill et al. 2005), but is more rapid in the post-metamorphic brainstem (described above). Maintenance of respiratory-related activity during brainstem hypoxia was due to anaerobic metabolism since the addition of iodoacetic acid to block glycolysis significantly shortened the time respiratory activity could be maintained prior to respiratory depression. The initial increase in lung ventilation in response to hypoxia was mimicked by noradrenaline application (Fournier et al. 2007) and abolished by application of the $\alpha_{1}$-adrenergic antagonist prazosin (Fournier et al. 2007) or transection of the brainstem at the level of the locus coeruleus, suggesting that structures within the midbrain are responsible for the hypoxic ventilatory decline of the isolated tadpole brainstem (Fournier and Kinkead 2008). Moreover, the initial hypoxic ventilatory decline of the isolated brainstem could be abolished by application of bumetanide, a selective $\mathrm{Na}^{+} / \mathrm{K}^{+} / 2 \mathrm{C}^{-}$co-transporter antagonist, suggesting that intact $\mathrm{Na}^{+} / \mathrm{K}^{+} / \mathrm{Cl}^{-}$co-transport is necessary for the excitatory component of the central $\mathrm{O}_{2}$ chemoreflex (Fournier and Kinkead 2008).

Recent studies have examined ventilatory plasticity in response to intermittent hypoxia in tadpoles (Simard et al. 2003). In bullfrog tadpoles, intermittent hypoxia $(45 \mathrm{mmHg}$ $\mathrm{PO}_{2}, 12 \mathrm{~h} /$ day, 2 weeks) did not modify the acute ventilatory response to hypoxia despite a significant increase in metabolic rate of animals exposed to intermittent hypoxia compared with control animals (Simard et al. 2003). Although intermittent hypoxia did not affect the acute ventilatory response to hypoxia, it did augment the acute ventilatory response to hypercarbia (Simard et al. 2003) indicating that respiratory plasticity does occur in response to intermittent hypoxia in tadpoles.

\section{Reptiles}

Reptiles uniformly possess an ectothermic, metabolic strategy, associated with low demands for oxygen at rest and relatively low aerobic scopes (Bennett and Dawson 1976). Extant reptiles, although paraphyletic in origin, are represented by a rather diverse group of animals, including Crocodylia (alligators, crocodiles), Testudines (turtles, tortoises and terrapins) and Lepidosaurians (lizards, snakes and amphisbaenids). This vertebrate group occupies an important phylogenetic position in vertebrate evolution as the stem group from which both the birds and mammals have arisen. Although modern reptiles have evolved independently for over 300 million years, the morphological and functional traits found within these species are the best representations of the ancestral phenotypes that gave rise to the basic functional features found in modern mammals and birds. The picture they present is a complex one as both the structure and function of their cardiovascular and ventilatory systems vary considerably among the different groups (Perry 1983; Hicks 1998).

Reptiles are found in a variety of aquatic and terrestrial habitats, distributed over a wide geographic range, from sea level to high altitude (from sea snakes and marine iguanas to various high altitude skinks lizards and chameleons). However, except for a few high altitude species (Naya et al. 2008), most extant reptiles rarely encounter environmental hypoxia. In spite of this, as with amphibians, most reptiles 
regularly experience large fluctuations in arterial $\mathrm{PO}_{2}$, resulting from intermittent breathing patterns (brief ventilatory periods, intermixed with variable periods of apnea) exacerbated by a variable pulmonary-systemic (R-L; pulmonary bypass) cardiac shunt.

\section{Ventilatory patterns in reptiles}

At rest, all reptiles are aspiration breathers, with expiration and inspiration being active (Wang et al. 1998). However, the precise mechanisms generating air flow into the lungs can be diverse; ranging from utilization of limb movements in testudines, contractions of hypaxial muscles in lizards and snakes, to the hepatic piston mechanism of crocodilians (Gans 1970; Wood and Lenfant 1976; Gans and Clark 1976; Clark et al. 1978; Liem 1985).

The "typical" ventilatory pattern exhibited in reptiles can be described as intermittent, consisting of either single breaths separated by periods of apnea of variable duration or short ventilatory bursts (several breaths) interspersed again, with variable apneic periods (for reviews see Milsom 1988, 1990, 1991). Although earlier studies suggested that aquatic species tended to show longer apnea durations compared to terrestrial species, there are many exceptions and no generalizations probably exist. Given these intermittent ventilatory patterns, numerous studies have demonstrated that whenever minute ventilation increases, either in response to changes in temperature, metabolism, or exposure to hypoxia, the increases result predominantly from a reduction of the non-ventilatory periods (e.g. Glass and Johansen 1976; Glass et al. 1985; Milsom 1988, 1991).

Response to hypoxia in reptiles

As discussed for anurans, the vast majority of studies on ventilatory control and the HVR in reptiles have been confined to relatively brief (minutes to hours) exposures to hypoxia. In general, when exposed to hypoxia reptiles increase breathing frequency by shortening the duration of the non-ventilatory periods (apnea), but increases in tidal volume, particularly at more severe levels of hypoxia, also contribute to the HVR (e.g. Milsom 1991; Wang et al. 1998). There is a large intra-species variability in this regard, however. Because this group is relatively hypoxia tolerant, the reptilian HVR is typically hyperbolic in shape and levels of $\mathrm{O}_{2}$ below $10 \%$ are often required to elicit a response. This threshold, however, is markedly temperature sensitive and increased temperature drastically increases sensitivity (e.g. Glass et al. 1983). While the HVR has been characterized in most major groups of reptiles, the studies have typically consisted of a series of progressive exposures to increasingly more severe hypoxia and, in most studies, the data have been averaged over time courses that make it difficult to distinguish whether any of the other short-term (seconds to minutes) time domains that have been described in mammals occur (short-term potentiation and short-term depression). Furthermore, virtually nothing is known about the mechanisms associated with intermittent hypoxia (progressive augmentation, longterm facilitation), or the mechanisms identifiable during or following prolonged hypoxic exposures (hypoxic ventilatory decline, ventilatory acclimatization to hypoxia, ventilatory deacclimatization from hypoxia and hypoxic desensitization). Given the absence of this information, we can only provide a brief overview of the current state of the field.

Regulation of arterial $\mathrm{O}_{2}$ in reptiles involves peripheral chemoreceptors (e.g. Jones and Milsom 1982; Milsom and Burleson 2007). The central vascular tree in reptiles and its innervation vary tremendously between groups and the $\mathrm{O}_{2}$ chemoreceptors distributed throughout this area have not been studied in much detail in most species. It seems, however, that all groups possess the equivalents of both carotid and aortic bodies (Milsom and Burleson 2007) and there is strong evidence for oxygen-sensitive chemoreceptors on the pulmonary artery throughout the reptiles also (Adams 1958, 1962; Benchetrit et al. 1977; Ishii et al. 1985a; Ishii and Ishii 1986). For example, groups of glomus-like cells are found in the adventitia of the carotid artery in turtles and lizards (Kobayashi 1971; Kusakabe et al. 1988). In turtles similar cells have also been found in the aortic arch and pulmonary artery. These glomus-like cells may contain catecholamines or serotonin (Kobayashi 1971; Ishii et al. 1985b; Chiba and Yamaguchi 1973). In snakes or crocodilians, no structures resembling glomus cells or specific neurotransmitters related to the HVR have been identified. This remains a potential fruitful area of research.

Although the precise cellular basis underlying $\mathrm{O}_{2}$ chemoreception and accompanying transmitter release from glomus cells is far from understood, changes in $\mathrm{PO}_{2}$ are thought to be the specific stimulus. The $\mathrm{PO}_{2}$ within the glomus cells is determined by oxygen delivery (the product of blood flow and blood $\mathrm{O}_{2}$ content) and $\mathrm{O}_{2}$ consumption of the chemoreceptor structure. A chemoreceptor can, therefore, sense blood $\mathrm{O}_{2}$ content if hemoglobin bound $\mathrm{O}_{2}$ participates in $\mathrm{O}_{2}$ delivery to the receptor (Lahiri et al. 1980, 1981). In reptiles and amphibians, the ventilatory responses to hypoxia at different temperatures are well correlated with arterial $\mathrm{O}_{2}$ content (Glass et al. 1983) and this correlation has fostered the hypothesis that the arterial chemoreceptors in these animals are sensitive to arterial $\mathrm{O}_{2}$ content, or alternatively hemoglobin oxygen saturation (reviewed by Boggs 1995). However, in testudines experimental reductions in blood oxygen carrying capacity do 
not affect the HVR (Wang et al. 1997). One possible explanation that could reconcile these observations would be that $\mathrm{O}_{2}$ sensing involves a heme protein with similar temperature-dependent oxygen-binding characteristics as hemoglobin (Boggs 1995).

Response to hypoxemia in reptiles

Several species, particularly freshwater turtles, have the capacity to alter the magnitude of their R-L shunt. During non-ventilatory periods, the level of $\mathrm{R}-\mathrm{L}$ shunt can increase to levels that are $>90 \%$ of the total cardiac output (Hicks and Wang 1998). During such periods, the arterial oxygen content is greatly diminished, with arterial oxygen approaching mixed venous levels. Interestingly, these large R-L shunts are initiated within minutes of apnea and continue throughout the prolonged non-ventilatory period. Thus internally generated hypoxemia does not appear to stimulate ventilation (Wang et al. 1997). It remains a mystery, therefore, as to why exposure to moderate environmental hypoxia elicits a significant increase in minute ventilation with significant reduction in the non-ventilatory periods, whereas the ventilatory control system appears to be insensitive to internally generated hypoxemia (through the development of R-L shunt). Obviously this paradoxical finding results from some complex integration between the cardiovascular and ventilatory control areas of the brain and remains an area that warrants further investigation.

Developmental changes in the HVR of juvenile reptiles

To our knowledge there are no data on developmental changes in the HVR of reptiles.

\section{The effects of temperature in ectotherms}

While physiological processes tend to be temperature dependent; studies on mammals and birds overlook the effects of temperatures on the time domains of the HVR because the body temperatures of these animals are maintained constant. It is expected, however, that if body temperatures change, the lengths of the individual time domains would change in an inverse manner due to a changes in activity at the cellular level (altered enzyme activity and metabolic rate). Other than its effect on response rates, temperature may also alter time domains in other ways.

The effects of temperature on the oxygen supply and demand of fish are twofold: first, the oxygen content of water varies inversely with temperature and secondly, oxygen consumption varies proportionally with temperature.
Therefore, an increase in temperature causes increases in resting ventilation rates as well as in responses to hypoxia and vice versa. These changes are not totally straightforward, however. Carp (C. carpio) acclimated to 10 and $20^{\circ} \mathrm{C}$ and exposed to mild to moderate hypoxia show no timedependent changes in total ventilation volume (Glass et al. 1990) (Fig. 8a), while carp acclimated to the same temperatures but exposed to severe hypoxia do show time-dependent changes (Stecyk and Farrell 2002) (Fig. 8b). These time domains exhibited by carp exposed to severe hypoxia were also inversely related to acclimation temperature.

Ventilatory responses to hypoxia in amphibians and reptiles are also highly temperature dependent. Invariably, the hypoxic threshold for elevated ventilation increases as body temperature rises (Jackson 1971, 1973; Glass et al. 1983; Kruhøffer et al. 1987; Dupre et al. 1989; Rocha and Branco 1998; Gamperl et al. 1999; Bicego-Nahas et al. 2001) (Fig. 9). Over a broad range of body temperatures the hypoxic ventilatory threshold seems to correlate well with arterial $\mathrm{O}_{2}$ content or $\mathrm{HbO}_{2}$ saturation in a number of species. This observation has lead to the speculation that the ventilatory response to hypoxia is determined by arterial $\mathrm{O}_{2}$ content or $\mathrm{HbO}_{2}$ saturation [possibly acting via an $\mathrm{O}_{2}$ sensing heme protein with similar temperature-dependent

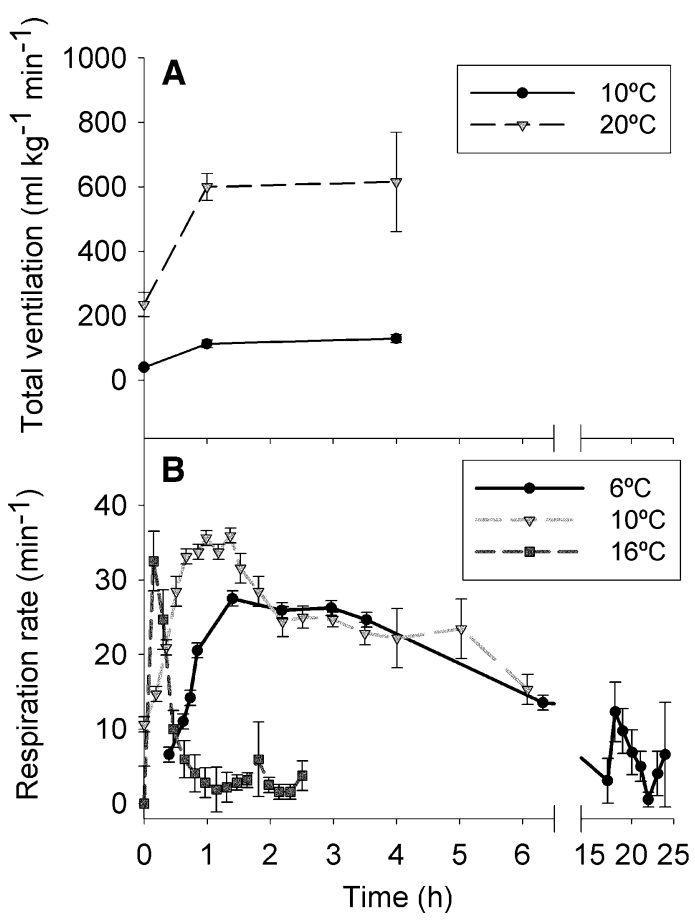

Fig. 8 Temperature affects time domains of the breathing rate $\left(\mathrm{min}^{-1}\right)$ in carp (Cyprinus carpio) exposed to a mild hypoxia $(75 \mathrm{mmHg})$ and $\mathbf{b}$ anoxia. Time-dependent changes are not evident with exposure to mild hypoxia but are observed by $2 \mathrm{~h}$ at $16^{\circ} \mathrm{C}$. The same response takes $6 \mathrm{~h}$ to develop at $10^{\circ} \mathrm{C}$ and about $20 \mathrm{~h}$ at $6^{\circ} \mathrm{C}$ (modified from Glass et al. 1990; Stecyk and Farrell 2002) 


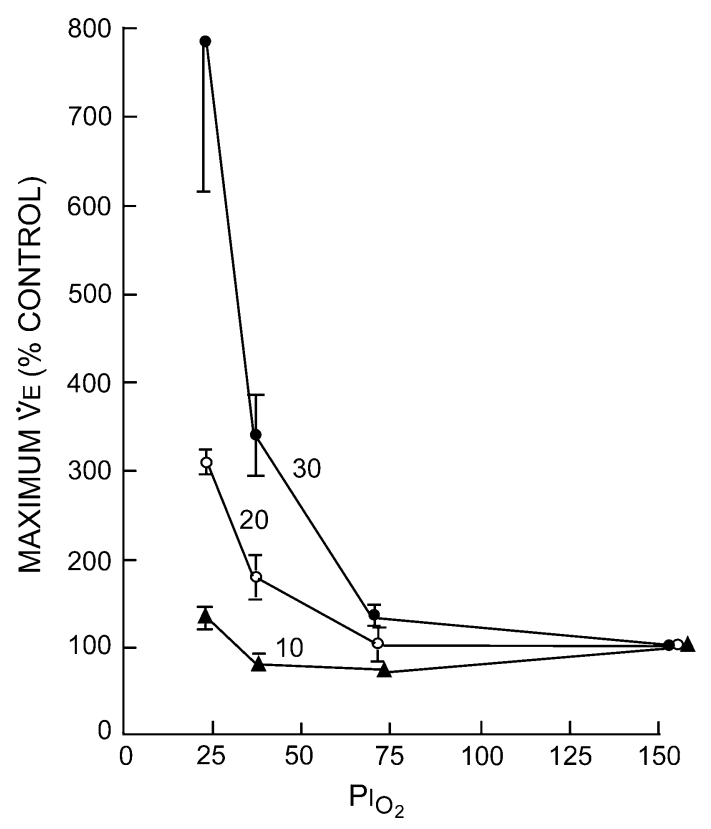

Fig. 9 The effects of body temperature on the hypoxic ventilatory response in the freshwater turtle, Pseudemys scripta elegans. Ventilation is expressed as \% of air breathing (control) (from Jackson 1973) (reprinted from Jackson 1973, Copyright (2010), with permission from Elsevier)

oxygen-binding characteristics as hemoglobin (Boggs 1995)]. The reduction in HVR with declining body temperatures has been documented in numerous ectothermic vertebrates (frogs, toads, lizards and turtles) as well as heterothermic mammals and birds (Heistand et al. 1950; Shelton et al. 1986; McArthur and Milsom 1991; Boggs 1995).

\section{Consequences of the hypoxic metabolic response in ectotherms}

Ectotherms in general are more prone to suppress metabolism in hypoxia than mammals and use this strategy along with changes in ventilation in order to match oxygen supply to oxygen demand. The net result should be higher levels of tissue and/or venous $\mathrm{PO}_{2}$ for any given level of arterial $\mathrm{PO}_{2}$. Whenever possible, reductions in overall metabolic demands during periods of moderate to severe hypoxia result in part from behavioral reductions in preferred body temperature, decreasing aerobic demands of the tissues via the " $Q_{10}$ effect". In addition, at a constant body temperature, animals can actively down-regulate ATP demands. Together, the reduction in aerobic demand lessens the potentially detrimental effects of hypoxia on overall oxygen transport.

Hypoxic-induced behavioral reduction of preferred body temperature was initially described in the plains minnow,
Hybognathus placitus (Bryan et al. 1984) and independently discovered in squamate reptiles (Hicks and Wood 1985). In the latter study, four phylogenetically diverse species of lizards each exhibited significant reductions in preferred body temperature following exposure to environmental hypoxia (inspired $\mathrm{O}_{2}<85 \mathrm{mmHg}$ ). This hypoxia-induced reduction in body temperature has subsequently been measured in many different species of ectothermic animals (Branco et al. 1993, 2000; BicegoNahas et al. 2001; Wood 1991).

The hypoxic-induced behavioral reductions in body temperature are due to changes in thermal set point(s) (Cabanac 1975) and are most likely a regulated response to reduced oxygen delivery (Wood 1991; Steiner and Branco 2002). This response, which is opposite to fever, has been termed anapyrexia by some (Cabanac and Massonnet 1980; Steiner and Branco 2002) and as the "hypoxic metabolic response" by others (Barros et al. 2001; Powell and Fu 2008). The latter seems more appropriate since, to add to the complexity of the situation, the HMR has now also been shown to incorporate timedependent processes (Bishop et al. 2000; Seifert and Mortola 2002) and to parallel the HVR in many ways. The precise mechanism(s) responsible for this response remains poorly understood. Steiner and Branco (2002) have suggested that several putative mediators such as arginine vasopressin (AVP), lactate, adenosine, histamine, endogenous opioids, $\mathrm{NO}, \mathrm{CO}$, and the cyclic nucleotides cAMP and cGMP acting in the central nervous system are involved in the response. Regardless of mechanism, the lowering of thermal set-points and the corresponding reduction of metabolic demands is a phylogenetically universal response to limited oxygen supply.

Hypoxia-induced active down-regulation of ATP demands at constant body temperature has also been described in several ectothermic species (Jackson 1968; West and Boutilier 1998; Buck and Pamenter 2006). Most studies on metabolic down-regulation in reptiles have focused on aquatic species, particularly freshwater turtles, and the mechanisms that enable these animals to survive extended periods of anoxia. When exposed to acute anoxia, freshwater turtles reduce heat production by as much as 85\% within hours (Jackson and Schmidt-Nielsen 1966; Jackson 1968). Hicks and Wang (1999) also investigated the effects of progressive hypoxia on oxygen consumption in the turtle, Trachemys scripta at $25^{\circ} \mathrm{C}$. In this study, the animals were anaesthetized and artificially ventilated for precise control of inspired gases and measurement of arterial and venous blood gases, $\mathrm{pH}$, and cardiac output. Reductions in inspired $\mathrm{O}_{2}$, and the subsequent fall in arterial and venous $\mathrm{PO}_{2}$ and $\mathrm{O}_{2}$ content resulted in a significant reduction in oxygen consumption $(73 \%$ of the normoxic value). In all animals, the reduction in oxygen 
consumption at the lowest inspired $\mathrm{O}_{2}$ was rapidly reversed upon return to normoxia. The underlying mechanism(s) remains unknown although indirect evidence suggests that it is not due to $\mathrm{O}_{2}$ limitation since metabolic rate could still be increased with 2,4-dinitrophenol injections. The HMR is likely due, in part, to suppression of ATPconsuming activities, for example downregulation of $\mathrm{Na}^{+}$ pump activity, and various synthetic pathways (Buck and Hochachka 1993; Hochachka and Lutz 2001).

The net result is that in all ectotherms there is a reported tendency for ventilation to fall as arterial $\mathrm{O}_{2}$ tensions fall below the $P_{\text {crit }}$ for a species (the critical $\mathrm{PO}_{2}$ at which a species switches from being an oxyregulator to an oxyconformer; i.e. the threshold $\mathrm{PO}_{2}$ at which metabolic suppression first occurs) (see Perry et al. 2009 for review). Presumably as long as time-dependent changes in the HVR are only considered at $\mathrm{O}_{2}$ tensions above the $P_{\text {crit }}$ of a species, this should not be an issue. At $\mathrm{O}_{2}$ tensions below the $P_{\text {crit }}$ of a species, however, things become quite complex.

\section{Consequences of circadian and circannual cycles in ectotherms}

Time of the day has been shown to affect the ventilatory response to hypoxia, in mammals (Stephenson et al. 2000; Jarsky and Stephenson 2000; Mortola and Seifert 2002; Mortola 2004), birds (Woodin and Stephenson 1998), and reptiles (Reyes and Milsom 2009) (Fig. 10). It is unclear what the mechanisms underlying day-night changes in ventilatory responses are, although interesting species specific differences are apparent. Circadian changes in respiratory sensitivity are independent of circadian changes in metabolism, activity or temperature (Reyes and Milsom 2009) and may be due to changes in the sensitivity of the peripheral arterial chemoreceptors per se. However, there may also be changes in the levels of baseline blood gases due to daily changes in the magnitude of the cardiac shunt and, to add to the complexity, similar changes in baseline blood gas tensions initiated from different baseline blood gas levels may give rise to different responses due to the non-linearity of the HVR (the same change in blood gases may not amount to the same change in stimulus when starting from different baselines).

Amphibians and reptiles also show seasonal differences in their ventilatory response to hypoxia, independent of changes in temperature. The effects of seasonal acclimatization on the HVR have been examined for the toad $B$. paracnemis (Bicego-Nahas et al. 2001) and the bullfrog $L$. catesbeianus (Rocha and Branco 1998). Summer-acclimatized toads exhibited a significant increase in ventilation in response to hypoxia at $25^{\circ} \mathrm{C}$ compared with winter
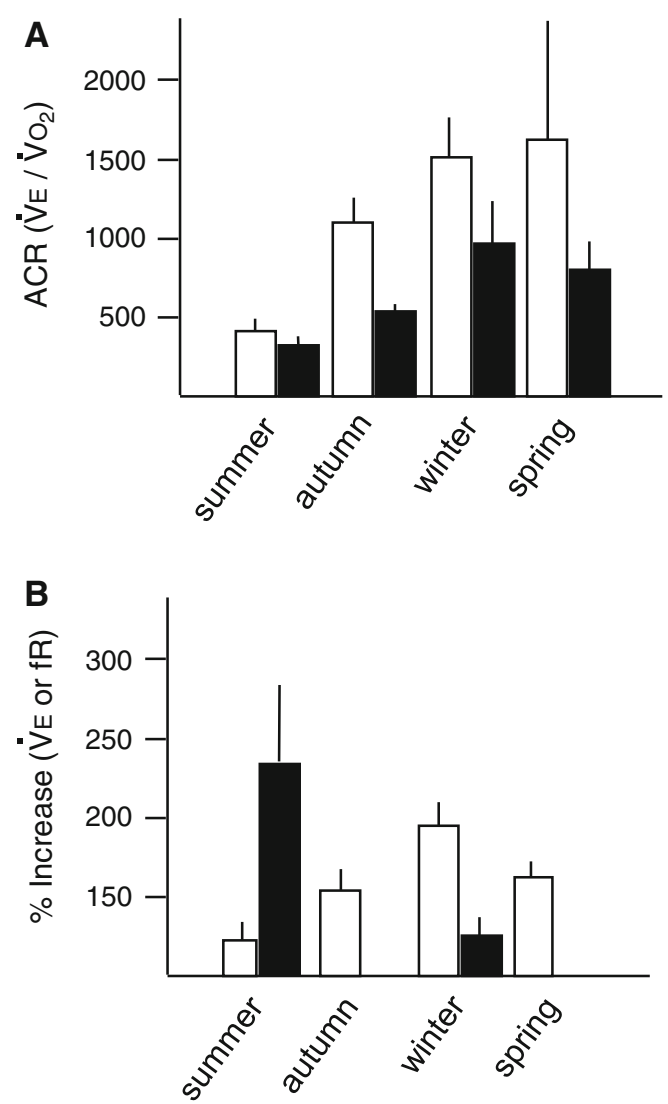

Fig. 10 a Day and night values of the air convection requirement $(\mathrm{ACR}) \pm \mathrm{SEM}$ of turtles breathing a hypoxic-hypercapnic $\left(8 \% \mathrm{O}_{2}\right.$, $\left.3 \% \mathrm{CO}_{2}\right)$ gas in different seasons measured at mean seasonal temperatures and natural photocycle (summer: $20.8^{\circ} \mathrm{C}, 16 \mathrm{~h}: 8 \mathrm{~h} \mathrm{~L}: \mathrm{D}$; autumn: $14.7^{\circ} \mathrm{C}, 10 \mathrm{~h}: 14 \mathrm{~h} \mathrm{~L}: \mathrm{D}$; winter: $9^{\circ} \mathrm{C}, 9 \mathrm{~h}: 15 \mathrm{~h} \mathrm{~L}: \mathrm{D}$; spring: $\left.14.6^{\circ} \mathrm{C}, 14 \mathrm{~h}: 10 \mathrm{~h} \mathrm{~L}: \mathrm{D}\right)$. b Seasonal differences in the magnitude of the ventilatory response (\% change) of bullfrogs $[\%$ change in breathing frequency $\left(f_{\mathrm{R}}\right)$ ] and toads ( $\%$ change in pulmonary ventilation $\left.V_{\mathrm{E}}\right)$ to hypoxia $\left(7-10 \% \mathrm{O}_{2}\right)$ at $25^{\circ} \mathrm{C}$ (modified from Reyes and Milsom 2009)

animals (Bicego-Nahas et al. 2001). Contrary to this, bullfrogs acclimatized to winter conditions had a lower hypoxic threshold and exhibited a significant increase in breathing frequency compared with summer-acclimatized animals when both were exposed to $10 \% \mathrm{O}_{2}$ at $25^{\circ} \mathrm{C}$ (Rocha and Branco 1998). Because winter bullfrogs had a higher resting $\mathrm{PaCO}_{2}$ and lower resting ventilation, the results may suggest an interactive effect of $\mathrm{CO}_{2}$ in the HVR that accounts for the different responses between the two groups of animals (Mayhew 1965; Bennett and Dawson 1976; Gregory 1982; Ultsch 1989; Zari 1999; Bicego-Nahas et al. 2001). In turtles, on the other hand, it would appear that winter reductions in both the temperature corrected resting ventilation and in the ventilatory response to hypoxia take place as a result of a carefully coordinated fall in metabolism (Reyes and Milsom 2009) (Fig. 10).

These circadian and circannual effects add yet another level of complexity to interpretation of changes in the HVR 
and the HMR during prolonged exposures to hypoxia. To what extent changes seen during prolonged hypoxic exposures (hypoxic ventilatory decline, ventilatory acclimatization to hypoxia, ventilatory deacclimatization from hypoxia and hypoxic desensitization) reflect circadian or circannual changes and to what extent they are independent of them remains unknown. This raises the further question of whether or not circadian and circannual rhythms in $\mathrm{O}_{2}$ sensitivity show time-dependent changes during chronic hypoxic exposures reflecting metaplasticity in the system.

\section{Summary}

The HVR is an ancestral trait. Oxygen is much less soluble in water than in air and hypoxia is far more common in aquatic environments. As a result, aquatic organisms must ventilate far more to obtain the same oxygen (their air convection requirement is an order of magnitude larger) and in the process rapidly excrete $\mathrm{CO}_{2}$. Thus while the primary drive to breathe for aquatic organisms is the need to obtain oxygen, for terrestrial organisms it becomes the need to eliminate $\mathrm{CO}_{2}$. Thus, in the phylogenetic progression from fish to terrestrial animals we see a reduction from $\mathrm{O}_{2}$ sensing at multiple internal and external sites throughout the gills and their associated blood vessels to one internal site only in birds and mammals (the carotid bodies) and an overall reduction in hypoxia tolerance. Given this trend it is surprising how little we know of the time domains of the HVRs in ectothermic vertebrates. In this review we have attempted to provide an overview of the existing literature on the topic within the framework of the hierarchical levels of the $\mathrm{O}_{2}$ transport cascade and the levels of the ventilatory control circuit at which they occur.

It becomes apparent that to define time domains for ectotherms in an environmentally relevant fashion requires modification to the terms as they have been rigorously defined for mammals. For mammals, these terms all refer to changes in the HVR due to hypoxia per se (i.e. not to concomitant changes in drive from other sources) (Powell et al. 1998). In studies of animals under more natural conditions, however, subsequent changes in respiratory drive accompany the HVR and these include not only the decreases in $\mathrm{CO}_{2}$ occurring as a result of the hypoxia induced increases in ventilation (the more natural condition), but also the decreases in metabolic rate that occur with hypoxia in many species. We propose that to accommodate more typical experiments in ectotherms we expand the terms to incorporate changes in both the primary and secondary processes that effect ventilation. One must keep in mind, however, that it is the mechanisms behind the time-dependent changes in ventilation rather than the time courses per se that must be carefully considered in order to draw parallels to the time domains observed in mammals and to reflect on evolutionary trends in the HVR.

Virtually all ectotherms have an immediate acute response to hypoxia of some sort. This is the response occurring in the first few breaths following changes in $\mathrm{O}_{2}$ levels at the peripheral chemoreceptors. The challenge for quantifying this response in ectotherms is determining when the signal at the peripheral chemoreceptors has stabilized. In aquatic organisms, it is difficult to produce an immediate acute change in $\mathrm{O}_{2}$ levels and for terrestrial ectotherms that breathe episodically, between the long apneas and the time it takes to turn over and stabilize gases in large saccular lungs, it can also take a prolonged period for arterial gas levels to stabilize. All of these factors must be taken into account in determining when the acute response is over and effects of the other short time domains begin.

Short-term depression and potentiation, as defined in mammals, are responses occurring in seconds to minutes, involving mechanisms not dependent on changes in levels of gene expression or protein synthesis (Powell et al. 1998). Short-term potentiation appears to be present in ectotherms (in fish at least) (Table 1). It may occur to either breathing frequency or tidal volume. At present it is not clear, however, whether the secondary increases in breathing that occur over these time periods are due to direct effects of hypoxia per se or the secondary changes in $\mathrm{CO}_{2} / \mathrm{pH}$, metabolism or intra-cardiac shunt. There have been few reports of anything similar to short-term depression to date although it has been documented in post-metamorphic and adult anuran brainstems in vitro (Winmill et al. 2005; Fournier and Kinkead 2006, 2008; Fournier et al. 2007).

Repeated responses to intermittent hypoxia have not been described in any ectotherms and so it is not known whether progressive augmentation or long-term facilitation occur in this group. Given the widespread occurrence of intermittent hypoxia in some aquatic environments, this warrants further investigation.

Longer term responses to prolonged hypoxic exposure (hypoxic ventilatory decline, ventilatory acclimatization to hypoxia, ventilatory deacclimatization from hypoxia and hypoxic desensitization) (Fig. 1) may involve mechanisms ranging from neurophysiological or neurochemical changes in the ventilatory control pathways (Powell et al. 1998), to subsequent changes in other aspects of respiratory drive, as well as changes occurring at other levels of the $\mathrm{O}_{2}$ transport cascade [e.g. the oxygen carrying capacity of red blood cells, modulation of cardiac function (particularly cardiac shunt and vascular tone)]. There is good evidence of hypoxic ventilatory decline occurring in some (but not all) ectotherms (Table 1) although, again, the time course of these events is slower than those seen in carefully controlled studies in mammals. 
Table 1 List of different time domains in the hypoxic ventilatory response documented to date in ectotherms

\begin{tabular}{|c|c|c|c|c|c|c|}
\hline Group & Time domain & Variable & Direction & Time course & Species & References \\
\hline \multirow[t]{5}{*}{ Fish } & STP & $V_{\mathrm{amp}} / V_{\mathrm{f}}$ & Increase & $5-15 \mathrm{~min}$ & Amia calva & McKenzie et al. (1991) \\
\hline & HVD & $V_{\text {amp }}$ & Decrease & $1-6 \mathrm{~h}$ & Colossoma macropoтит & $\begin{array}{l}\text { Rantin and Kalinin (1996) } \\
\text { Florindo et al. (2006) }\end{array}$ \\
\hline & HVD & $V_{\mathrm{f}}$ & Decrease & $1-12 \mathrm{~h}$ & Cyprinius carpio & Stecyk and Farrell (2002) \\
\hline & VAH & $V_{\text {amp }}$ & Increase & $7-21$ days & Platichthys flesus & Kerstens et al. (1979) \\
\hline & & & & & Ictalurus punctatus & Burleson et al. (2002) \\
\hline \multirow[t]{8}{*}{ Amphibians } & STD & Fictive & Decrease & $30 \mathrm{~min}$ & Rana catesbeiana & Winmill et al. (2005) \\
\hline & & & & & & Fournier et al. (2007) \\
\hline & HVD & $V_{\mathrm{amp}} / V_{\mathrm{f}}$ & Decrease & $30-180 \mathrm{~min}$ & Bufo paracnemis & Gargaglioni and Branco (2000) \\
\hline & & & & & Rana catesbeiana & Winmill et al. (2005) \\
\hline & & & & & Lithobates catesbeianus & Fournier et al. (2007) \\
\hline & VAH & $V_{\mathrm{f}}$ & Decrease & $7-10$ days & Bufo marinus & Gamperl et al. (1999) \\
\hline & & & & & & McAneney et al. (2006) \\
\hline & & & & & & Srivaratharajah et al. (2008) \\
\hline
\end{tabular}

STP short-term potentiation, $S T D$ short-term depression, $H V D$ hypoxic ventilatory decline, $V A H$ ventilatory acclimatization to hypoxia, fictive fictive ventilation

Ventilatory acclimatization to hypoxia also appears to be present in some fish and amphibians although the direction of the changes seen in each group is opposite raising questions about the mechanisms involved (and the need for yet another term) (Table 1).

If we are to distinguish between the genetic, developmental and environmental influences underlying the various ventilatory responses to hypoxia, then it will be critical to design future experiments with the shortcomings of the existing literature in mind. Careful attention must be given to the rate of onset of hypoxia, the length and intensity of the hypoxic exposure, the components of the HVR being examined (e.g. respiratory volume vs. breathing frequency) and the time course over which data are averaged. For ectothermic vertebrates, it is especially critical to pay attention to the effects of temperature since onset time and duration of different time domains of the HVR may vary with $Q_{10}$. It is important to measure changes in metabolic rate since hypoxic metabolic suppression is so common in ectotherms. Finally, for those species capable of intracardiac shunting, it must be remembered that this may be as important a strategy for dealing with hypoxia as the HVR itself and that changes in shunting will lead to changes in the need for a ventilatory response. The study of time domains of the HVR and HMR in ectotherms are other areas ripe for future research.

Acknowledgments We are grateful to our funding agencies, the Natural Sciences and Engineering Research Council of Canada, the Danish Research Council, the National institute Institutes of Health (MSH: NIH SO6 GM48135) and the National Science Foundation (JWH: NSF IOS-0922756 and MSH: NSF IOS-0843082) for their continuing support.
Open Access This article is distributed under the terms of the Creative Commons Attribution Noncommercial License which permits any noncommercial use, distribution, and reproduction in any medium, provided the original author(s) and source are credited.

\section{References}

Adams WE (1958) The comparative morphology of the carotid body and carotid sinus. Ch. C Thomas, Springfield

Adams WE (1962) The carotid sinus-carotid body problem in chelonian (with a note on a foramen of pannizza in Dermochelys). Arch Int Pharmacodyn Ther 139:28-37

Andersen JB, Hedrick MS, Wang T (2003) Cardiovascular responses to hypoxia and anaemia in the toad Bufo marinus. J Exp Biol 206:857-865

Babiker MM (1979) Respiratory behaviour, oxygen consumption and relative dependence on aerial respiration in the African lungfish (Protopterus annectens, Owen) and an air-breathing teleost (Clarias lazera C.). Hydrobiologia 65:177-187

Bamford OS (1974) Oxygen reception in the rainbow trout (Salmo gairdneri). Comp Biochem Physiol 48A:69-76

Barros RCH, Zimmer ME, Branco LGS, Milsom WK (2001) Hypoxic metabolic response of the golden-mantled ground squirrel. J Appl Physiol 91:603-612

Benchetrit G, Armand J, Dejours P (1977) Ventilatory chemoreflex drive in the tortoise Testudo horsfieldii. Repir Physiol 31:183-191

Bennett AF, Dawson WR (1976) Metabolism. In: Gans C, Dawson WR (eds) Biology of the Reptilia, vol 5. Academic Press, New York, pp 127-223

Bicego-Nahas KC, Gargaglioni LH, Branco LG (2001) Seasonal changes in the preferred body temperature, cardiovascular, and respiratory responses to hypoxia in the toad, Bufo paracnemis. J Exp Zool 289:359-365

Bickford D, Iskandar D, Barlian A (2008) A lungless frog discovered on Borneo. Curr Biol 18:R374-R375

Bishop B, Silva G, Krasney J, Salloum A, Roberts A, Nakano H, Shucard D, Rifkin D, Farkas G (2000) Circadian rhythms of 
body temperature and activity levels during $63 \mathrm{~h}$ of hypoxia in the rat. Am J Physiol 279:R1378-R1385

Boggs DF (1995) Hypoxic ventilatory control and hemoglobin oxygen affinity. In: Sutton JR, Houston CS, Coates G (eds) Hypoxia and the brain. Queen City Printers, Burlington, pp 69-86

Borch K, Jensen F, Andersen B (1993) Cardiac activity, ventilation rate and acid-base regulation in rainbow trout exposed to hypoxia and combined hypoxia and hypercapnia. Fish Physiol Biochem 12:101-110

Boutilier RG (1988) Control of arrhythmic breathing in bimodal breathers: Amphibia. Can J Zool 66:6-19

Boutilier RG, Toews DP (1977) The effect of progressive hypoxia on respiration in the toad Bufo marinus. J Exp Biol 68:99-107

Boutilier RG, Randall DJ, Shelton G, Toews DP (1979) Acid-base relationships in the blood of the toad, Bufo marinus. III. The effects of burrowing. J Exp Biol 82:357-365

Branco LGS, Glass ML (1995) Ventilatory responses to carboxyhaemoglobinaemia and hypoxic hypoxia in Bufo paracnemis. J Exp Biol 198:1417-1421

Branco LG, Portner HO, Wood SC (1993) Interaction between temperature and hypoxia in the alligator. Am J Physiol Regul Integr Comp Physiol 265:R1339-R1343

Branco LG, Steiner AA, Tattersall GJ, Wood SC (2000) Role of adenosine in the hypoxia-induced hypothermia of toads. Am J Physiol Regul Integr Comp Physiol 279:R196-R201

Bryan JD, Neill WH, Hill LG (1984) Interdependence of acute temperature preference and respiration in the plains minnow. Trans Am Fish Soc 113:557-562

Buck LT, Hochachka PW (1993) Anoxic suppression of Na(+)-K(+)ATPase and constant membrane potential in hepatocytes: support for channel arrest. Am J Physiol Regul Integr Comp Physiol 265:R1020-R1025

Buck LT, Pamenter ME (2006) Adaptive responses of vertebrate neurons to anoxia-matching supply to demand. Respir Physiol Neurobiol 154:226-240

Burggren WW, Doyle M (1986) Ontogeny of regulation of gill and lung ventilation in the bullfrog, Rana catesbeiana. Respir Physiol 66:279-291

Burggren WW, Just JJ (1992) Developmental changes in physiological systems. In: Feder ME, Burggren WW (eds) Environmental physiology of the amphibians. University of Chicago Press, Chicago, pp 467-530

Burggren WW, Mwalukoma A (1983) Respiration during chronic hypoxia and hyperoxia in larval and adult bullfrogs (Rana catesbeiana). I. Morphological responses of lungs, skin and gills. J Exp Biol 105:191-203

Burggren WW, Pan T-C (2009) Chemoreceptive control of ventilation in amphibians and air-breathing fishes. In: Zaccone G, Cutz E, Adriaensen D, Nurse CA, Mauceri A (eds) Airway chemoreceptors in the vertebrates-structure evolution and function. Science Publishers, Enfield, pp 151-183

Burggren WW, West NH (1982) Changing respiratory importance of gills, lungs and skin during metamorphosis in the bullfrog Rana catesbeiana. Respir Physiol 47:151-164

Burggren WW, Smits A, Evans B (1989) Arterial $\mathrm{O}_{2}$ homeostasis during diving in the turtle Chelodina longicollis. Respir Physiol 78:265-280

Burleson ML, Milsom WK (1995) Cardio-ventilatory control in rainbow trout: I. Pharmacology of branchial, oxygen-sensitive chemoreceptors. Respir Physiol 100:231-238

Burleson ML, Carlton AL, Silva PE (2002) Cardioventilatory effects of acclimatization to aquatic hypoxia in channel catfish. Respir Physiol Neurobiol 131:223-232

Burleson ML, Mercer SE, Wilk-Blaszczak MA (2006) Isolation and characterization of putative $\mathrm{O}_{2}$ chemoreceptor cells from the gills of channel catfish (Ictalurus punctatus). Brain Res 1092:100-107

Bushnell PG, Brill RW (1992) Oxygen transport and cardiovascular responses in skipjack tuna (Katsuwonus pelamis) and yellowfin tuna (Thunnus albacares) exposed to acute hypoxia. J Comp Physiol B 162:131-143

Cabanac M (1975) Temperature regulation. Annu Rev Physiol 37:415-439

Cabanac M, Massonnet B (1980) Pathology of thermoregulation. Rev Neurol (Paris) 136:285-302

Chan F, Barth JA, Lubchenco J, Kirincich A, Weeks H, Peterson WT, Menge BA (2008) Emergence of anoxia in the California current large marine ecosystem. Science 319:920

Chiba T, Yamaguchi A (1973) Fluorescence and microscopy of the monoamine-containing cells in the turtle heart. Cell Tissue Res 140:26-37

Ciuhandu CS, Wright PA, Goldberg JI, Stevens ED (2007) Parameters influencing the dissolved oxygen in the boundary layer of rainbow trout (Oncorhynchus mykiss) embryos and larvae. J Exp Biol 210:1435-1445

Clark BD, Gans C, Rosenberg HI (1978) Air flow in snake ventilation. Respir Physiol 32:207-212

Coelho F, Smatresk NJ (2003) Resting respiratory behavior in minimally instrumented toads-effects of very long apneas on blood gases and $\mathrm{pH}$. Braz J Biol 63:35-45

Coolidge EH, Ciuhandu CS, Milsom WK (2008) A comparative analysis of putative oxygen-sensing cells in the fish gill. J Exp Biol 211:1231-1242

Crocker CE, Ultsch GR, Jackson DC (1999) The physiology of diving in a north-temperate and three tropical turtle species. J Comp Physiol B 169:249-255

Crowder WC, Nie M, Ultsch GR (1998) Oxygen uptake in bullfrog tadpoles (Rana catesbeiana). J Exp Zool 280:121-134

de Jongh HJ, Gans C (1969) On the mechanism of respiration in the bullfrog, Rana catesbeiana: a reassessment. J Morphol 127:259-290

Diaz RJ, Breitburg DL (2009) The hypoxic environment. In: Richards JG, Brauner CJ, Farrell AP (eds) Hypoxia. Academic Press, San Diego, pp 1-23

Dupre KR, Hicks JW, Wood SC (1989) Effect of temperature on chemical control of breathing in Mexican black iguanas. Am J Physiol 257:R1258-R1263

Eldridge FL, Milhorn DE (1986) Oscillation, gating, and memory in the respiratory control system. In: Cherniack NS, Widdicombe JG (eds) Handbook of physiology, section 3; the respiratory system: control of breathing, part 1, vol II. American Physiological Society, Washington, DC, pp 93-114

Florindo LH, Leite CAC, Kalinin AL, Reid SG, Milsom WK, Rantin FT (2006) The role of branchial and orobranchial $\mathrm{O}_{2}$ chemoreceptors in the control of aquatic surface respiration in the neotropical fish tambaqui (Colossoma macropomum): progressive responses to prolonged hypoxia. J Exp Biol 209:1709-1715

Forgue J, Burtin B, Massabuau J-C (1989) Maintenance of oxygen consumption in resting Silurus glanis at different levels of ambient oxygenation. J Exp Biol 143:305-319

Fournier S, Kinkead R (2006) Noradrenergic modulation of respiratory motor output during tadpole development: role of $\alpha$-adrenoceptors. J Exp Biol 209:3685-3694

Fournier S, Kinkead R (2008) Role of pontine neurons in central $\mathrm{O}_{2}$ chemoreflex during development in bullfrogs (Lithobates catesbeiana). Neuroscience 155:983-996

Fournier S, Allard M, Roussin S, Kinkead R (2007) Developmental changes in central $\mathrm{O}_{2}$ chemoreflex in Rana catesbeiana: the role of noradrenergic modulation. J Exp Biol 210:3015-3026 
Fritsche R, Nilsson S (1993) Cardiovascular and ventilatory control during hypoxia. In: Rankin JC, Jensen FB (eds) Fish ecophysiology. Chapman \& Hall, London, pp 180-206

Gamperl AK, Driedzic WR (2009) Cardiovascular function and cardiac metabolism. In: Richards JG, Brauner CJ, Farrell AP (eds) Hypoxia. Academic Press, San Diego, pp 302-361

Gamperl AK, Milsom WK, Farrell AP, Wang T (1999) Cardiorespiratory responses of the toad (Bufo marinus) to hypoxia at two different temperatures. J Exp Biol 202:3647-3658

Gans C (1970) Strategy and sequence in the evolution of the external gas exchangers of ectothermal vertebrates. Form Funct 3:61-104

Gans C, Clark B (1976) Studies on ventilation of Caiman crocodilus (Crocodilia: Reptilia). Respir Physiol 26:285-301

Gardner MN, Smits AW, Smatresk NJ (2000) The ventilatory responses of the caecilian Typhlonectes natans to hypoxia and hypercapnia. Physiol Biochem Zool 73:23-29

Gargaglioni LH, Branco LGS (2000) Role of nucleus isthmi in the ventilatory response to hypoxia of Bufo paracnemis. Respir Physiol 119:31-39

Gargaglioni LH, Branco LGS (2001) Effects of nitric oxide in the nucleus isthmi on the hypoxic and hypercarbic drive to breathing of toads. Am J Physiol 281:R338-R345

Gargaglioni LH, Milsom WK (2007) Control of breathing in anuran amphibians. Comp Biochem Physiol A 147:665-684

Garland TJ, Adolph SC (1994) Why not to do two-species comparative studies: limitations on inferring adaptation. Physiol Zool 67:797-828

Garland T, Carter PA (1994) Evolutionary physiology. Annu Rev Physiol 56:579-621

Gilmour KM (2001) The $\mathrm{CO}_{2} / \mathrm{pH}$ ventilatory drive in fish. Comp Biochem Physiol A 130:219-240

Glass ML, Johansen K (1976) Control of breathing in Acrochordus javanicus. Physiol Zool 49:328-340

Glass ML, Soncini R (1999) Physiological shunts in gils of teleost fish: assessment of the evidence. In: Val AL, Almeida-Val VMF (eds) Biology of tropical fishes. IMPA, Manaus, pp 333-340

Glass ML, Boutilier RG, Heisler N (1983) Ventilatory control of arterial $\mathrm{PO}_{2}$ in the turtle, Chrysemys picta belli: effects of temperature and hypoxia. J Comp Physiol 151:145-153

Glass ML, Boutilier RG, Heisler N (1985) Effects of body temperature on respiration, blood gases and acid-base status in the turtle Chrysemys picta bellii. J Exp Biol 114:37-51

Glass ML, Ishimatsu A, Johansen K (1986) Responses of aerial ventilation to hypoxia and hypercapnia in Channa argus, an airbreathing fish. J Comp Physiol B 156:425-430

Glass ML, Andersen NA, Kruhoffer M, Williams EM, Heisler N (1990) Combined effects of environmental $\mathrm{PO}_{2}$ and temperature on ventilation and blood gases in the carp Cyprinus carpio L. J Exp Biol 148:1-17

Glass ML, Fernandes MS, Soncini R, Glass H, Wasser JS (1997) Effects of dry season dormancy on oxygen uptake, heart rate, and blood pressures in the toad, Bufo paracnemis. J Exp Zool 279:330-336

Goniakowska-Witalinska L, Pecio A, Podkowa D (2009) Neuroendocrine cells in the lungs of amphibians and air-breathing fishes. In: Zaccone G, Cutz E, Adriaensen D, Nurse CA, Mauceri A (eds) Airway chemoreceptors in the vertebratesstrucure evolution and function. Science Publishers, Enfield, pp 99-123

Gordon MS (1969) Hydrostatic pressure. In: Hoar WS, Randall DJ (eds) Fish physiology. Academic Press, New York, pp 445-464

Gracey AY, Troll JV, Somero GN (2001) Hypoxia-induced gene expression profiling in the euryoxic fish Gillichthys mirabilis. Proc Natl Acad Sci USA 98:1993-1998

Graham JB (1997) Air-breathing fishes: evolution, diversity and adaptation. Academic Press, San Diego
Gregory PT (1982) Reptilitan hibernation. In: Gans C (ed) Biology of the reptilian. Academic Press, London, pp 53-154

Guppy M, Withers PC (1999) Metabolic depression in animals: physiological perspectives and biochemical generalizations. Biol Rev 74:1-40

Hedrick MS, Chen AK (2009) Hypoxic ventilatory depression is attenuated by blockade of K(ATP) channels and adenosine receptors in the isolated bullfrog brainstem. FASEB $\mathbf{J}$ 23:621-624

Hedrick MS, Katz SL, Jones DR (1994) Periodic air-breathing behaviour in a primitive fish revealed by spectral analysis. J Exp Biol 197:429-436

Hedrick MS, Drewes RC, Hillman SS, Withers PC (2007) Lung ventilation contributes to vertical lymph movement in anuran amphibians. J Exp Biol 210:3940-3945

Heistand WA, Rochold WT, Stemmler FW, Stullken DE, Wiebers JE (1950) Comparative hypoxic resistance of hibernators and nonhibernators. Physiol Zool 23:264-269

Hicks JW (1998) Cardiac shunting in reptiles: mechanisms, regulation and physiological functions. In: Gans C, Gaunt AS (eds) Biology of the Reptilia. Morphology G: visceral organs, vol 19. Society for the Study of Amphibians and Reptiles, Ithaca, pp 425-483

Hicks JW, Wang T (1996) Functional role of cardiac shunts in reptiles. J Exp Zool 275:204-216

Hicks JW, Wang T (1998) Cardiovascular regulations during anoxia in the turtle: an in vivo study. Physiol Zool 71:1-14

Hicks JW, Wang T (1999) Hypoxic hypometabolism in the anesthetized turtle, Trachemys scripta. Am J Physiol 277:R18-R23

Hicks JW, Wood SC (1985) Temperature regulation in lizards: effects of hypoxia. Am J Physiol Regul Integr Comp Physiol 248:R595R600

Hillman SS, Withers PC, Drewes RC, Hillyard SD (2009) Ecological and environmental physiology of amphibians. Oxford University Press, New York

Hillman SS, Hedrick MS, Drewes RC, Withers PC (2010) Lymph flux rates from various lymph sacs in the cane toad Rhinella marina: an experimental evaluation of the roles of compliance, skeletal muscles and the lungs in the movement of lymph. J Exp Biol 213:3161-3166

Hochachka PW, Lutz PL (2001) Mechanism, origin, and evolution of anoxia tolerance in animals. Comp Biochem Physiol 130B:435-459

Holeton GF (1971) Respiratory and circulatory responses of rainbow trout larvae to carbon monoxide and to hypoxia. J Exp Biol 55:683-694

Hou P-CL, Huang S-P (1999) Metabolic and ventilatory responses to hypoxia in two altitudinal populations of the toad, Bufo bankorensis. Comp Biochem Physiol A 124:413-421

Hughes GM, Sunders RL (1970) Responses of the respiratory pumps to hypoxia in the rainbow trout (Salmo gairdneri). J Exp Biol 53:529-545

Ishii K, Ishii K (1986) Glossopharyngeal innervation of chemo- and barroreceptorsin the dorsal carotid arteryof the tortoise Testudo hermanni. Repir Physiol 65:295-302

Ishii K, Ishii K, Kusakabe T (1985a) Chemo- and baroreceptor innervation of the aortice trunk of the toad Bufo vulgaris. Repir Physiol 60:365-375

Ishii K, Ishii K, Kusakabe T (1985b) Electophysiological aspects of reflexogenic area in the chlonian, Geoclemmys reevesii. Respir Physiol 59:45-54

Jackson DC (1968) Metabolic depression and oxygen depletion in the diving turtle. J Appl Physiol 24:503-509

Jackson DC (1971) The effect of temperature on ventilation in the turtle Pseudemys scripta elegans. Respir Physiol 12:131-140

Jackson DC (1973) Ventilatory responses to hypoxia in turtles at various temperatures. Respir Physiol 18:178-187 
Jackson DC, Schmidt-Nielsen K (1966) Heat production during diving in the fresh water turtle, Pseudemys scripta. J Cell Physiol 67:225-232

Jared C, Navas CA, Toledo RC (1999) An appreciation of the physiology and morphology of the Caecilians (Amphibia: Gymnophiona). Comp Biochem Physiol A 123:313-328

Jarsky TM, Stephenson R (2000) Effects of hypoxia and hypercapnia on circadian rhythms in the golden hamster (Mesocricetus auratus). J Appl Physiol 89:2130-2138

Jensen FB (1991) Multiple strategies in oxygen anc carbon dioxide transport by haemoglobin. In: Woakes AJ, Grieshaber MK, Bridges CR (eds) Physiological strategies for gas exchange and metabolims. Cambridge University Press, Cambridge, pp 55-78

Jensen FB, Fago A, Weber RE (1998) Hemoglobin structure and function. In: Perry SF, Tufts BL (eds) Fish respiration. Academic Press, San Diego, pp 1-40

Jesse MJ, Shub C, Fishman AP (1967) Lung and gill ventilation of the African lung fish. Respir Physiol 3:267-287

Jia XX, Burggren WW (1997a) Developmental changes in chemoreceptive control of gill ventilation in larval bullfrogs (Rana catesbeiana). I. Reflex ventilatory responses to ambient hyperoxia, hypoxia and NaCN. J Exp Biol 200:2229-2236

Jia XX, Burggren WW (1997b) Developmental changes in chemoreceptive control of gill ventilation in larval bullfrogs (Rana catesbeiana). II. Sites of $\mathrm{O}_{2}$-sensitive chemoreceptors. J Exp Biol 200:2237-2248

Jibb LA, Richards JG (2008) AMP-activated protein kinase activity during metabolic rate depression in the hypoxic goldfish, Carassius auratus. J Exp Biol 211:3111-3122

Johansen K, Lenfant C (1967) Respiratory function in the South American lungfish, Lepidosiren paradoxa (Fitz). J Exp Biol 46:205-218

Johansen K, Lenfant C (1968) Respiration in the African lungfish Protopterus aethiopicus: II. Control of breathing. J Exp Biol 49:453-468

Johansen K, Hanson D, Lenfant C (1970) Respiration in a primitive air breather, Amia calva. Respir Physiol 9:162-174

Jones RM (1982) How toads breathe: control of air flow to and from the lungs by the nares in Bufo marinus. Respir Physiol 49:251-265

Jones DR, Chu C (1988) Effect of denervation of carotid labyrinths on breathing in unrestrained Xenopus laevis. Respir Physiol 73:243-256

Jones DR, Milsom WK (1982) Peripheral receptors affecting breathing and cardiovascular function in non-mammalian vertebrates. J Exp Biol 100:59-91

Jonz MG, Nurse CA (2005) Development of oxygen sensing in the gills of zebrafish. J Exp Biol 208:1537-1549

Jonz MG, Fearon IM, Nurse CA (2004) Neuroepithelial oxygen chemoreceptors of the zebrafish gill. J Physiol 560:737-752

Jørgensen CB (2000) Amphibian respiration and olfaction and their relationships: from Robert Townson (1794) to the present. Biol Rev 75:297-345

Kerstens A, Lomholt JP, Johansen K (1979) The ventilation, extraction and uptake of oxygen in undisturbed flounders, Platichthys flesus: responses to hypoxia acclimation. J Exp Biol 83:169-179

Kinkead R, Fritsche R, Perry SF, Nilsson S (1991) The role of circulating catecholamines in the ventilatory and hypertensive responses to hypoxia in the Atlantic cod (Gadus morhua). Physiol Zool 64:1087-1109

Kobayashi S (1971) Comparative cytological studies of the carotid body 1 . Demonstration of monoamine-storing cells by correlated chromaffin reaction and fluorescence hystochemistry. Archivum Histologicum Japonicum 33:319-339
Kruhøffer M, Glass ML, Abe AS, Johansen K (1987) Control of breathing in an amphibian Bufo paracnemis: effects of temperature and hypoxia. Respir Physiol 69:267-275

Kusakabe T (1991) Morphogenesis of the carotid labyrinth in the bullfrog, Rana catesbeiana, during larval development and metamorphosis. Anat Embryol 185:133-139

Kusakabe T (1992) Ultrastructural characteristics of glomus cells in the external carotid artery during development and metamorphosis in the bullfrog, Rana catesbeiana. Anat Rec 233:461-466

Kusakabe T, Ishii K, Ishii K (1988) Dense granule-containing cells in arterial chemoreceptor areas of the tortoise (Testudo hemanni). J Morphol 197:183-191

Kusakabe T, Powell FL, Ellisman MH (1993) Ultrastructure of the glomus cells in the carotid body of chronically hypoxic rats: with special reference to the similarity of amphibian glomus cells. Anat Rec 237:220-227

Lahiri S, Nishino T, Mokashi A, Mulligan E (1980) Relative responses of aortic body and carotid body chemoreceptors to hypotension. J Appl Physiol 48:781-788

Lahiri S, Mulligan E, Nishino T, Mokashi A, Davies RO (1981) Relative responses of aortic body and carotid body chemoreceptors to carboxyhemoglobinemia. J Appl Physiol 50:580-596

Leite C, Florindo L, Kalinin A, Milsom W, Rantin F (2007) Gill chemoreceptors and cardio-respiratory reflexes in the neotropical teleost pacu, Piaractus mesopotamicus. J Comp Physiol 193A:1001-1011

Liem KF (1985) Ventilation. In: Hildebrand M, Bramble DM, Liem KF, Wake DB (eds) Functional vertebrate morphology. Harvard University Press, Cambridge, pp 186-209

Lomholt JP, Johansen K (1979) Hypoxia acclimation in carp-how it affects $\mathrm{O}_{2}$ uptake, vantilation, and $\mathrm{O}_{2}$ extraction from water. Physiol Zool 52:38-49

MacIntyre DH, Toews DP (1976) The mechanics of lung ventilation and the effects of hypercapnia on respiration in Bufo marinus. Can J Zool 54:1364-1374

Mayhew WW (1965) Hibernation in the horned lizard, Phrynosoma m'calli. Comp Biochem Physiol 16:103-119

McAneney J, Reid SG (2007) Chronic hypoxia attenuates central respiratory-related $\mathrm{pH} / \mathrm{CO}_{2}$ chemosensitivity in the cane toad. Respir Physiol Neurobiol 156:266-275

McAneney J, Gheshmy A, Uthayalingam S, Reid SG (2006) Chronic hypoxia modulates NMDA-mediated regulation of the hypoxic ventilatory response in an amphibian, Bufo marinus. Respir Physiol Neurobiol 153:23-38

McArthur MD, Milsom WK (1991) Changes in ventilation and respiratory sensitivity associated with hibernation in Columbian (Spermophilus columbianus) and Golden-mantled (Spermophilus lateralis) ground squirrels. Physiol Zool 64:940-959

McDonald DG, McMahon BR (1977) Respiratory development in Arctic char Salvelinus alpinus under conditions of normoxia and chronic hypoxia. Can J Zool 55:1461-1467

McFarland WN, Moss SA (1967) Internal behavior in fish schools. Science 156:260-262

McKenzie DJ, Taylor EW (1996) Cardioventilatory responses to hypoxia and $\mathrm{NaCN}$ in the neotenous axolotl. Respir Physiol 106:255-262

McKenzie DJ, Burleson ML, Randall DJ (1991) The effects of branchial denervation and pseudobranch ablation on cardioventilatory control in an air-breathing fish. J Exp Biol 161:347-365

Milsom WK (1988) Control of arrhythmic breathing in aerial breathers. Can J Zool 66:99-108

Milsom WK (1990) Control and coordination of gas exchange in air breathers. In: Boutilier RG (ed) Advances in comparative and environmental physiology. Springer, Berlin, pp 347-400

Milsom WK (1991) Intermittent breathing. Annu Rev Physiol 53:87-105 
Milsom WK, Burleson ML (2007) Peripheral arterial chemoreceptors and the evolution of the carotid body. Respir Physiol Neurobiol 157:4-11

Milsom WK, Reid SG, Meier JT, Kinkead R (1999) Central respiratory pattern generation in the bullfrog, Rana catesbeiana. Comp Biochem Physiol A 124:253-264

Mortola JP (2004) Implications of hypoxic hypometabolism during mammalian ontogenesis. Respir Physiol Neurobiol 141:354-356

Mortola JP, Seifert EL (2002) Circadian patterns of breathing. Respir Physiol Neurobiol 131:91-100

Naya DE, Veloso C, Bozinovic F (2008) Physiological flexibility in the Andean lizard Liomaemus bellii: seasonal changes in energy acquisition, storage and expenditure. J Comp Physiol 178B:1007-1015

Neubauer JA, Melton JE, Edelman NH (1990) Modulation of respiration during brain hypoxia. J Appl Physiol 68:441-451

Nikinmaa M (2001) Haemoglobin function in vertebrates: evolutionary changes in cellular regulation in hypoxia. Respir Physiol 128:317-329

Nikinmaa M, Weber RE (1984) Hypoxic acclimation in the lamprey, Lampetra fluviatilis: organismic and erythrocytic responses. J Exp Biol 109:109-119

Noronha-de-Souza CR, Bicego K, Michel G, Glass ML, Branco LGS, Gargaglioni LH (2006) Locus coeruleus is a central chemoreceptive site in toads. Am J Physiol 291:R997-R1006

Nussbaum RA, Wilkinson M (1995) A new genus of lungless tetrapod: a radically divergent caecilian (Amphibia: Gymnophiona). Proc R Soc Lond B 261:331-335

Pack AI, Galante RJ, Fishman AP (1990) Control of interbreath interval in the African lungfish. Am J Physiol 28:R139-R146

Perry SF (1983) Reptilian lungs. Functional anatomy and evolution. Adv Anat Embryol Cell Biol 79:1-81

Perry SF, Gilmour KM (1996) Consequences of catecholamine release on ventilation and blood oxygen transport during hypoxia and hypercapnia in an elasmobranch Squalus acanthias and a teleost Oncorhynchus mykiss. J Exp Biol 199:2105-2118

Perry SF, Gilmour KM (2002) Sensing and transfer of respiratory gases at the fish gill. J Exp Zool 293:249-263

Perry SF, Gilmour KM (2006) Acid-base balance and $\mathrm{CO}_{2}$ excretion in fish: unanswered questions and emerging models. Respir Physiol Neurobiol 154:199-215

Perry SF, Wood CM (1989) Control and coordination of gas transfer in fishes. Can J Zool 67:2961-2970

Perry SF, Gilmour KM, Vulesevic B, McNeill B, Chew SF, Ip YK (2005) Circulating catecholamines and cardiorespiratory responses in hypoxic lungfish (Protopterus dolloi): a comparison of aquatic and aerial hypoxia. Physiol Biochem Zool 78:325-334

Perry SF, Euverman R, Wang T, Loong AM, Chew SF, Ip YK, Gilmour KM (2008) Control of breathing in African lungfish (Protopterus dolloi): a comparison of aquatic and cocooned (terrestrialized) animals. Respir Physiol Neurobiol 160:8-17

Perry SF, Jonz MG, Gilmour KM (2009) Oxygen sensing and the hypoxic ventilatory response. In: Richards JG, Brauner CJ, Farrell AP (eds) Hypoxia. Academic Press, San Diego, pp 194-255

Pinder AW, Burggren WW (1986) Ventilation and partitioning of oxygen uptake in the frog Rana pipiens: effects of hypoxia and activity. J Exp Biol 126:453-468

Powell FL, Fu Z (2008) HIF-1 and ventilatory acclimatization to chronic hypoxia. Respir Physiol Neurobiol 164:282-287

Powell FL, Milsom WK, Mitchell GS (1998) Time domains of the hypoxic ventilatory response. Respir Physiol 112:123-134

Rantin FT, Kalinin AL (1996) Cardiorespiratory function and aquatic surface respiration in Colossoma macropomum exposed to graded and acute hypoxia. In: Val AL, Almeida-Val VMF, Randall DJ (eds) Physiology and biochemistry of the fishes of the Amazon. Editora do INPA, Manaus, pp 169-180
Reid SG (2006) Chemoreceptor and pulmonary stretch receptor interactions within amphibian respiratory control systems. Respir Physiol Neurobiol 154:153-164

Reid SG, Sundin L, Florindo LH, Rantin FT, Milsom WK (2003) Effects of afferent input on the breathing pattern continuum in the tambaqui (Colossoma macropomum). Respir Physiol Neurobiol 136:39-53

Reyes C, Milsom WK (2009) Daily and seasonal rhythms in the respiratory sensitivity of red-eared sliders (Trachemys scripta elegans). J Exp Biol 212:3339-3348

Rocha PL, Branco LGS (1998) Seasonal changes in the cardiovascular, respiratory and metabolic responses to temperature and hypoxia in the bullfrog Rana catesbeiana. J Exp Biol 201:761-768

Rombough PJ (1998) Respiratory gas exchange, aerobic metabolism, and effects of hypoxia during early life. In: Hoar WS, Randall DJ (eds) Fish physiology. The physiology of the developing fish, part A eggs and larvae, vol 11. Academic Press, New York, pp 59-161

Rombough P, Moroz B (1997) The scaling and potential importance of cutaneous and branchial surfaces in respiratory gas exchange in larval and juvenile walleye. J Exp Biol 200:2459

Rose FL, Drotman RB (1967) Anaerobiosis in a frog, Rana pipiens. J Exp Zool 166:427-432

Saltys HA, Jonz MG, Nurse CA (2006) Comparative study of gill neuroepithelial cells and their innervation in teleosts and Xenopus tadpoles. Cell Tissue Res 323:1-10

Sanchez A, Soncini R, Wang T, Koldkjaer P, Taylor EW, Glass ML (2001) The differential cardio-respiratory responses to ambient hypoxia and systemic hypoxaemia in the South American lungfish, Lepidosiren paradoxa. Comp Biochem Physiol A Mol Integr Physiol 130:677-687

Sanders CE, Milsom WK (2001) The effects of tonic lung inflation on ventilation in the American bullfrog, Rana catesbeiana Shaw. J Exp Biol 204:2647-2656

Seifert EL, Mortola JP (2002) Circadian pattern of ventilation during prolonged hypoxia in conscious rats. Respir Physiol Neurobiol 133:23-34

Sheafor EA, Wood SC, Tattersall GJ (2000) The effect of graded hypoxia on the metabolic rate and buccal activity of a lungless salamander (Desmognathus fuscus). J Exp Biol 203:3785-3793

Shelton G, Jones DR, Milsom WK (1986) Control of breathing in ectothermic vertebrates. In: Fishman AP (ed) Handbook of physiology. William \& Wilkings Company, Baltimore, pp 857-909

Simard E, Trepanier G, Larochelle J, Kinkead R (2003) Intermittent hypoxia and plasticity of respiratory chemoreflexes in metamorphic bullfrog tadpoles. Respir Physiol Neurobiol 135:59-72

Smatresk NJ, Smits AW (1991) Effects of central and peripheral chemoreceptor stimulation on ventilation in the marine toad, Bufo marinus. Respir Physiol 83:223-238

Soivio A, Nikinmaa M, Westman K (1980) The blood oxygen binding properties of hypoxic Salmo gairdneri. J Comp Physiol [B] 136:83-87

Srivaratharajah K, Cui A, McAneney J, Reid SG (2008) Chronic hypoxic hypercapnia modifies in vivo and in vitro ventilatory chemoreflexes in the cane toad. Respir Physiol Neurobiol 160:249-258

Stecyk JAW, Farrell AP (2002) Cardiorespiratory responses of the common carp (Cyprinus carpio) to severe hypoxia at three acclimation temperatures. J Exp Biol 205:759-768

Steiner AA, Branco LGS (2002) Hypoxia-induced anapyrexia: implications and putative mediators. Annu Rev Physiol 64:263-288

Stephenson R, Mohan RM, Duffin J, Jarsky TM (2000) Circadian rhythms in the chemoreflex control of breathing. Am J Physiol 278:R282-R286 
Straus C, Wilson RJA, Remmers JE (2001) Oxygen sensitive chemoreceptors in the first gill arch of the tadpole, Rana catesbeiana. Can J Physiol Pharmacol 79:959-962

Sundin L, Turesson J, Taylor EW (2003) Evidence for glutamatergic mechanisms in the vagal sensory pathway initiating cardiorespiratory reflexes in the shorthorn sculpin Myoxocephalus scorpius. J Exp Biol 206:867-876

Taylor AC, Kollros JJ (1946) Stages in the normal development of Rana pipiens larvae. Anat Rec 94:7-24

Taylor JC, Miller JM (2001) Physiological performance of juvenile southern flounder, Paralichthys lethostigma (Jordan and Gilbert, 1884), in chronic and episodic hypoxia. J Exp Mar Biol Ecol 258:195-214

Thomas S, Hughes GM (1982a) Effects of hypoxia on blood gas and acid-base parameters of sea bass. J Appl Physiol 53:1336-1341

Thomas S, Hughes GM (1982b) A study of the effects of hypoxia on acid-base status of rainbow trout blood using an extracorporeal blood circulation. Respir Physiol 49:371-382

Truchot JP, Duhamel-Jouve A (1980) Oxygen and carbon dioxide in the marine intertidal environment: diurnal and tidal changes in rockpools. Respir Physiol 39:241-254

Turesson J, Sundin L (2003) N-methyl-D-aspartate receptors mediate chemoreflexes in the shorthorn sculpin Myoxocephalus scorpius. J Exp Biol 206:1251-1259

Turesson J, Schwerte T, Sundin L (2006) Late onset of NMDA receptor-mediated ventilatory control during early development in zebrafish (Danio rerio). Comp Biochem Physiol A 143:332339

Ultsch GR (1989) Ecology and physiology of hibernation and overwintering among freshwater fishes, turtles, and snakes. Biol Rev 64:435-516

Ultsch GR, Jackson DC (1982) Long-term submergence at $3{ }^{\circ} \mathrm{C}$ of the turtle, Chrysemys picta bellii, in normoxic and severely hypoxic water: I. Survival, gas exchange and acid-base status. J Exp Biol 96:11-28

Val AL, De Almeida-Val VMF (1995) Amazonian waters. Fishes of the Amazon and their environment physiological and biochemical aspects. Springer, Berlin, pp 4-27

Van Vliet BN, West NH (1992) Functional characteristics of arterial chemoreceptors in an amphibian (Bufo marinus). Respir Physiol $88: 113-127$

Vitalis TZ, Shelton G (1990) Breathing in Rana pipiens: the mechanism of ventilation. J Exp Biol 154:537-556

Vulesevic B, McNeill B, Perry SF (2006) Chemoreceptor plasticity and respiratory acclimation in the zebrafish Danio rerio. J Exp Biol 209:1261-1273

Wang T (1994) Measurement of ventilatory responses in the toad Bufo marinus: a comparison of pneumotachography and buccal pressures. Comp Biochem Physiol A 109:793-798

Wang T, Hicks JW (1996) The interaction of pulmonary ventilation and the right-left shunt on arterial oxygen levels. J Exp Biol 199:2121-2129

Wang T, Hicks JW (2002) An integrative model to predict maximum oxygen uptake of animals with central vascular shunts. Zoology 105:45-53
Wang T, Branco LGS, Glass ML (1994) Ventilatory responses to hypoxia in the toad Bufo paracnemis before and after a decrease in haemoglobin oxygen-carrying capacity. J Exp Biol 186:1-8

Wang T, Krosniunas E, Hicks JW (1997) The role of cardiac shunts in the regulation of arterial blood gases. Am Zool 37:12-22

Wang T, Smits AW, Burggren WW (1998) Pulmonary function in reptiles. In: Gans C, Gaunt AS (eds) Biology of the Reptilia. Morphology G: visceral organs, vol 19. Society for the Study of Amphibians and Reptiles, Ithaca, pp 297-374

Wang T, Taylor EW, Reid SG, Milsom WK (2004) Interactive effects of mechano- and chemo-receptor inputs on cardio-respiratory outputs in the toad. Respir Physiol Neurobiol 140:63-76

West TG, Boutilier RG (1998) Metabolic suppression in anoxic frog muscle. J Comp Physiol B 168:273-280

West NH, Burggren WW (1982) Gill and lung ventilatory responses to steady-state aquatic hypoxia and hyperoxia in the bullfrog tadpole. Respir Physiol 47:165-176

West NH, Jones DR (1975) Breathing movements in the frog Rana pipiens $\mathrm{I}$. The mechanical events associated with lung and buccal ventilation. Can J Zool 53:332-344

West NH, Van Vliet BN (1992) Sensory mechanisms regulating the cardiovascular and respiratory systems. In: Feder ME, Burggren WW (eds) Environmental physiology of the amphibians. University of Chicago Press, Chicago, pp 151-182

Winmill RE, Chen AK, Hedrick MS (2005) Development of the respiratory response to hypoxia in the isolated brainstem of the bullfrog Rana catesbeiana. J Exp Biol 208:213-222

Withers PC, Hillman SS (1983) The effects of hypoxia on pulmonary function and maximal rates of oxygen consumption in two anuran amphibians. J Comp Physiol 152:125-129

Wood SC (1982) The effect of oxygen affinity on arterial $\mathrm{PO}_{2}$ in animals with vascular shunts. J Appl Physiol 53:1360-1364

Wood SC (1984) Cardiovascular shunts and oxygen transport in lower vertebrates. Am J Physiol 247:R3-R14

Wood SC (1991) Interactions between hypoxia and hypothermia. Annu Rev Physiol 53:71-85

Wood SC, Johansen K (1972) Adaptation to hypoxia by increased $\mathrm{HbO}_{2}$ affinity and decreased red cell ATP concentration. Nat New Biol 237:278-279

Wood SC, Lenfant CJM (1976) Respiration: mechanics, control and gas exchange. In: Gans C, Dawson WR (eds) Biology of the reptilian. Academic Press, New York, pp 225-274

Woodin M, Stephenson R (1998) Circadian rhythms in diving behaviour and ventilatory response to asphyxia in canvasvack ducks. Am J Physiol 274:R68-R693

Youngson AF, Malcolm IA, Thorley JL, Bacon PJ, Soulsby C (2004) Long-residence groundwater effects on incubating salmonid eggs: low hyporheic oxygen impairs embryo development. Can J Fish Aquat Sci 61:2278-2287

Zari TA (1999) Seasonal acclimatization in metabolic rate of the fanfingered gecko, Ptyodactylus hasselquistii (Reptilia: Gekkonidae). J Therm Biol 24:137-142 